\title{
الوقف ذو الإجارة الواحدة وموقف الفقهاء منه
}

$$
\text { إعداد }
$$

\section{口الدكتورة إقبال عبدالعزيز المطوع}

أستاذة الفقه-قسم الدراسات الإسلامية

كلية التربية الأساسية

\section{المقدمة}

بسم الله الحمد لله و الصالاة و السلام على أشرف خلق الله محمد بن عبــــالله وعلى آل بيته الطيبين الأطهار، وصحبه المبرئين الأخيار إلى يوم الدين.

والانتفاع بالأعيان الموقوفة سواء كانت عقارات أو منقولات يختلف الانتفاع ها باختلاف ما أعدت له على حسب شرط الواقف والمذكور في صك وقفه. فإذا نص الو اقف في وقفه على كيفية الانتفاع بالعين التي وقفهــا، وكـــان

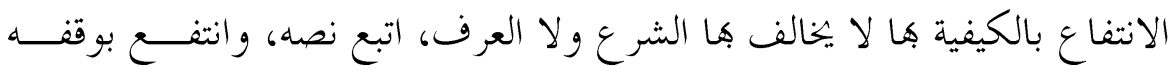
على الوجه الذي نص عليه، وإذا لم يكن هنالك نص معين يبين كيفية الانتفـــاع هذا الوقف، انتفع به على الوجه الذي تعارف عليه الويها شرعاً.

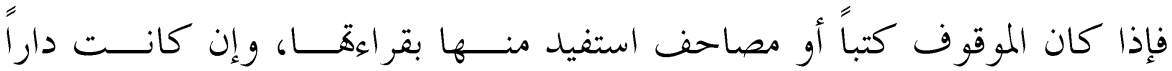
سكنت وأجرت، المهمم أن يستفاد من الوقف ولا يركن ويهمل حتى يخرب، ومن وجوه الاستفادة والانتفاع ما سنذكره في بكثنا هذا، ألا وهو الانتفاع بالإيجار. 
فعقد الإجارة يعتبر من أكثر أساليب الصيغ الاستثمارية الاقتصادية التي لجأت

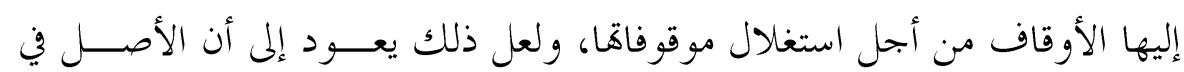

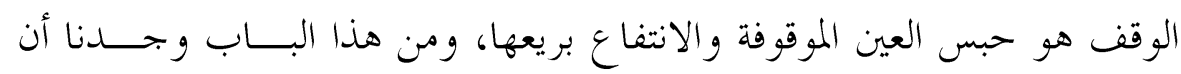
الإيجار استخدم كصيغة مهمة للانتفاع بالاعيان الموقوفة. وهنا فرق بسيط بين عقد الإجارة الذي يقع في الملك عنه في الوقف، حيث

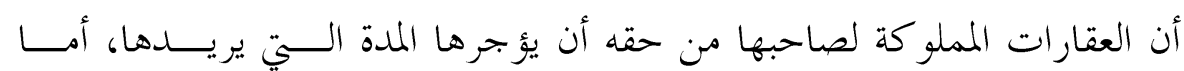
عقارات الوقف فالواقف حريص عليها من التلف والضياع، لذلك فهو يمدد مدة

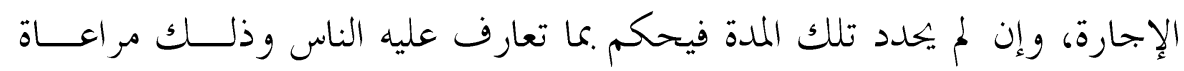
لمصالح الوقف.

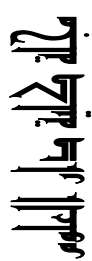

$r \cdot r$

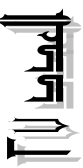
وهناك عدة طرق لإيبجار التي سأذكرها ضمن المباحث التالية: المبحث الأول: الوقف ذو الإجارة الواحدة. ويتكون من المطالب التالية: المطلب الأول: رأي الفقهاء في تأجير العين الموقوفة. المطلب الثاني: من له حق تأجير العين الموقوفة. المطلب الثالث: مقدار الأجرة. المطلب الرابع: مدة إجارة الوقف. المطلب الخامس: انتهاء مدة الإجارة. وأما المبحث الثاني: الوقف ذو الإجارتين. هذا وأسأل الله تعالى أن أوفق في عرض هذه المباحث على الوجه المطلوب. 


\section{المبحث الأول

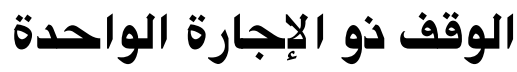 \\ المطلب الأول : رأي الفقهاء في تأجير العين الموقوفتة:

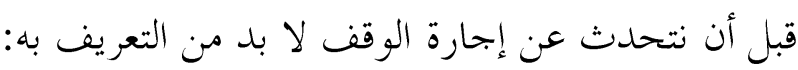

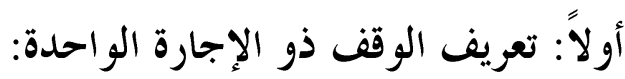

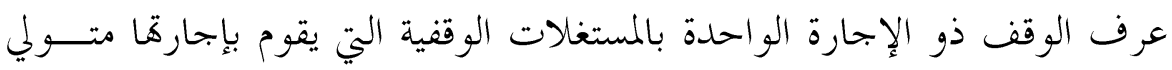

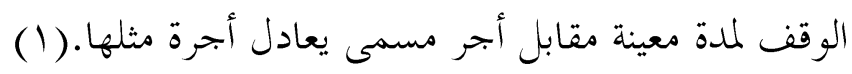

ثانياً: التكييف الشرعي للوقف ذو الإجارة الواحدة:

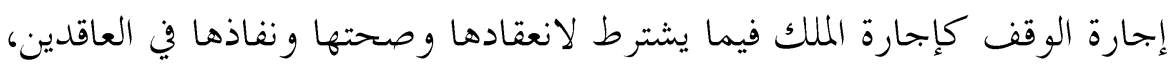

국.

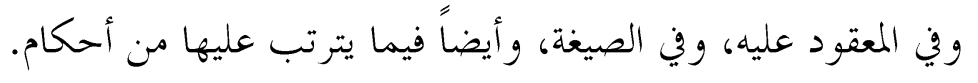

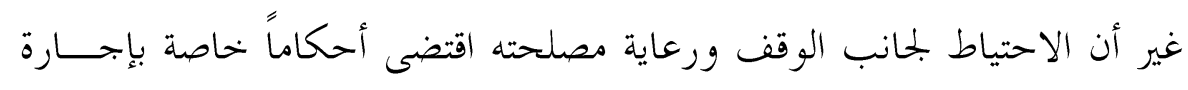

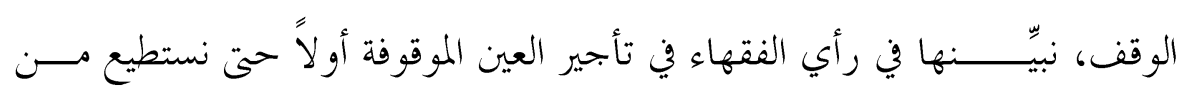

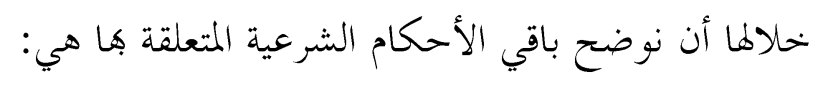

㺼 ( أ ) رأي الفقهاء في تأجير العين الموقوفة:

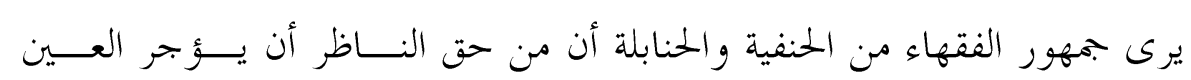

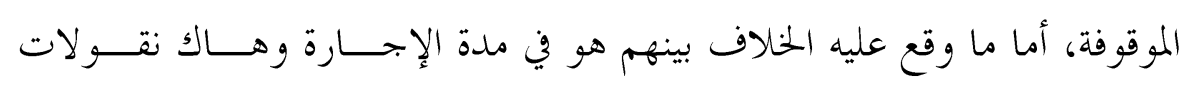
أصحاهم في جواز التأجير.

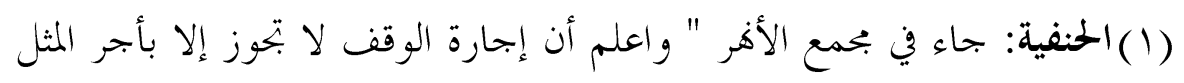

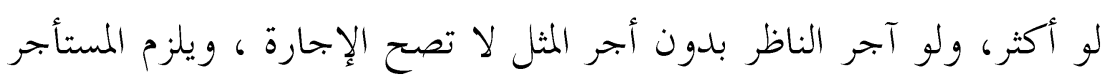

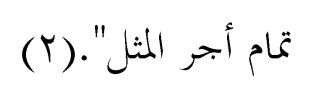

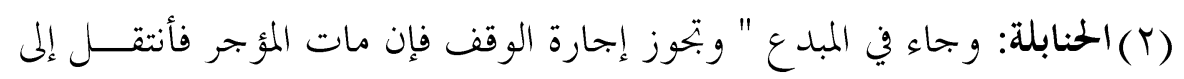

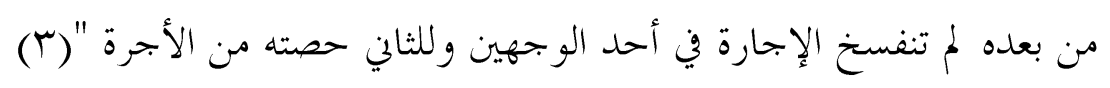




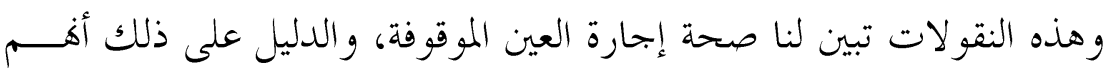
اختلفوا في مدة الإجارة على ما سأبينه لاحقاً.

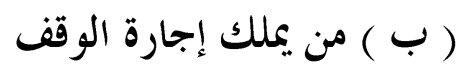

إن الذي يملك استغلال الوقف بالإجارة ونوها من مز ارعة ومساقاة، إنما

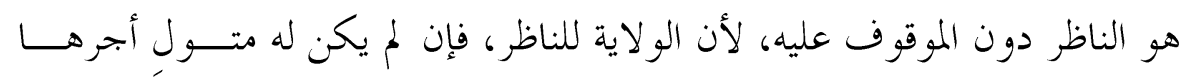

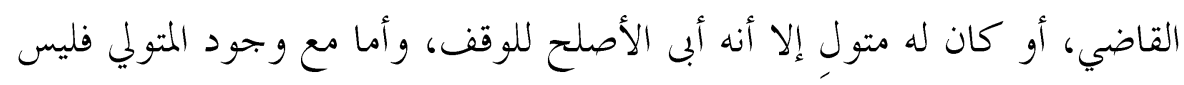

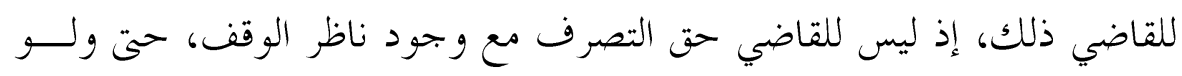

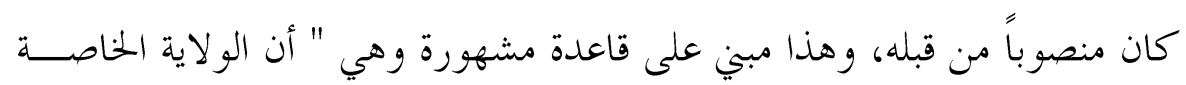

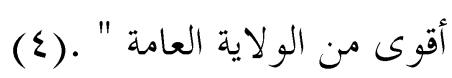

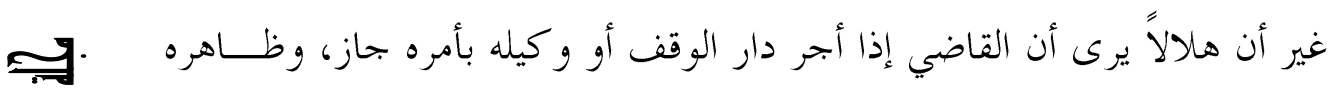

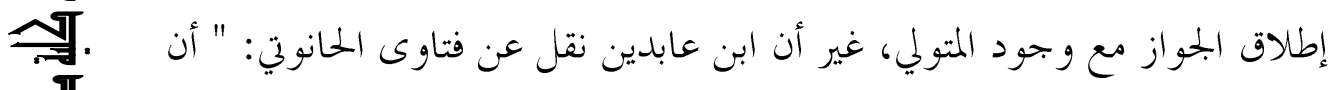

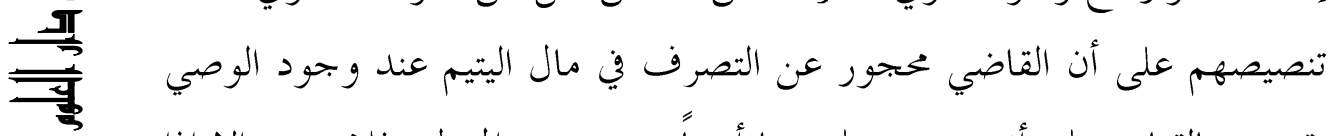
$\mu \cdot \varepsilon$

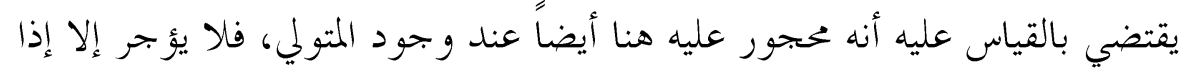

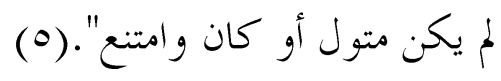

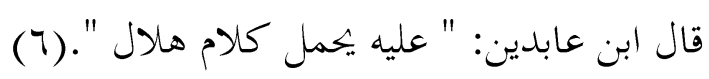

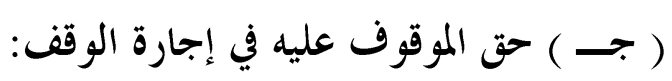

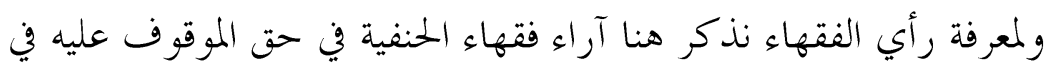
إجحارة الوقف و التي لا بد فيها لنا من التفرقة بين حالتين:

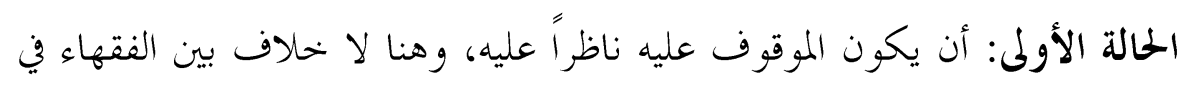

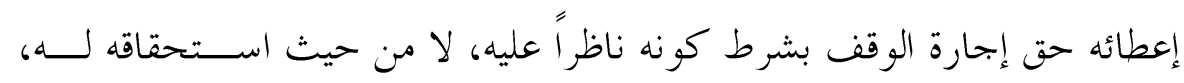
وهو الذي عليه الفتوى. (v) 
وفي هذا المعنى يقول ابن الهمام: " ونص الأشتروسني أنه رأى في المنقول أن إجارة

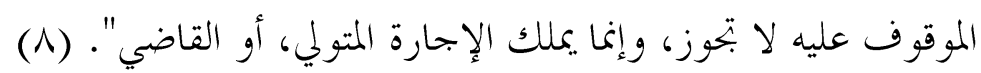

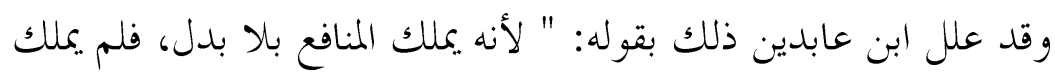

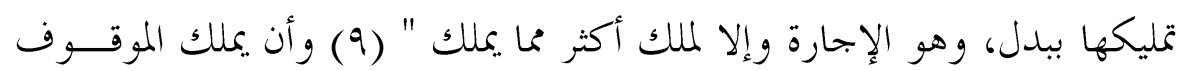

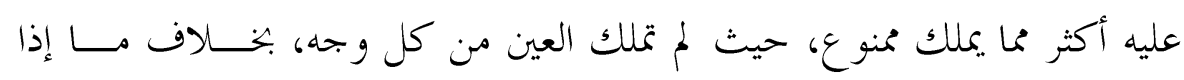

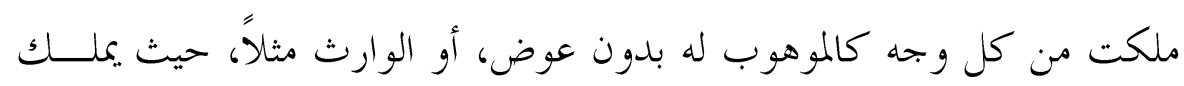

$$
\text { البيع والهبة بعوض. }
$$

\section{( د ) حق الموقوف عليه في الإعارة}

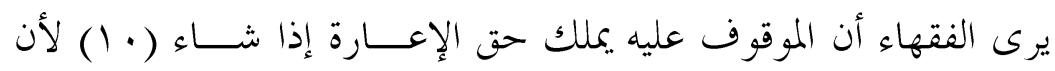

ज्ञ

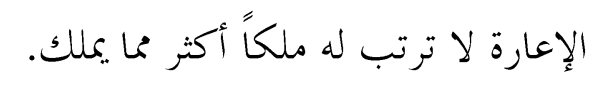

ونرى الخصاف يعلل صحة الإعارة مع عدم صحة الإجسـارة بقولــه: "

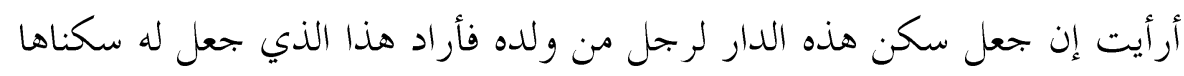

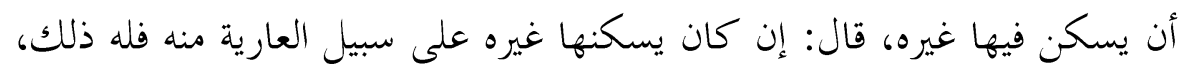

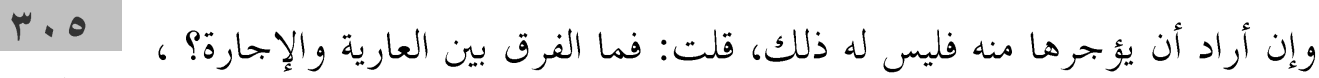

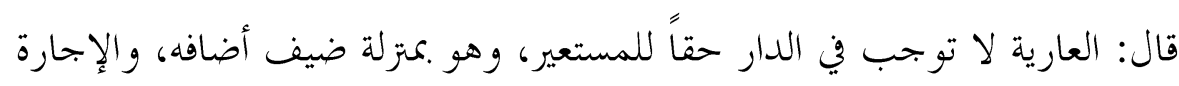
يجب للمستأجر فيها حق بالإجارة ". (11)

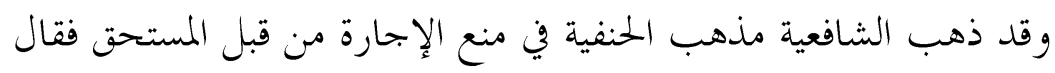

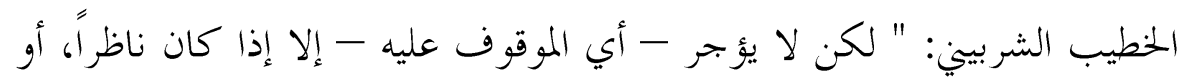

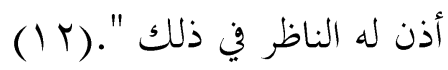

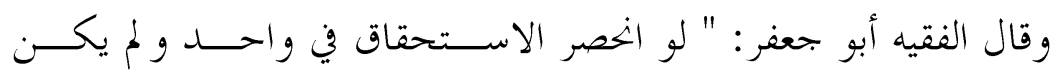

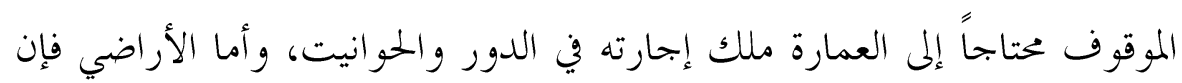

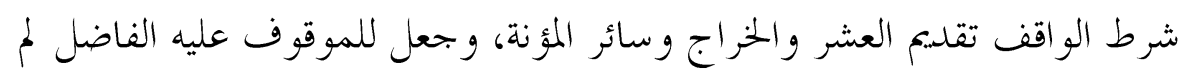




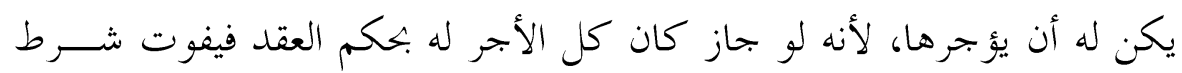

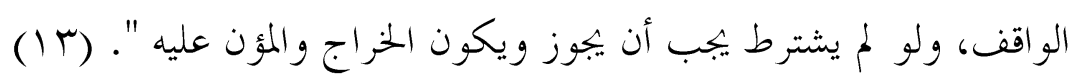
( هـ ) ما يترتب على عدم إجارة المستحق:

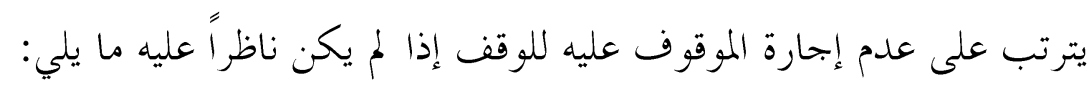

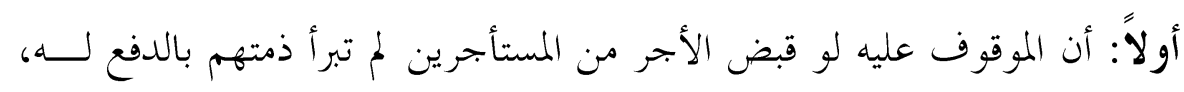

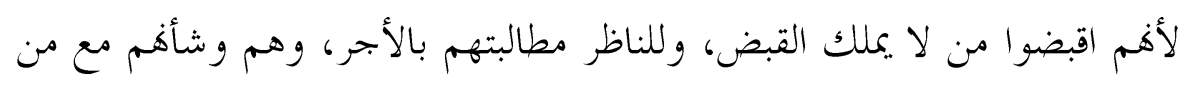

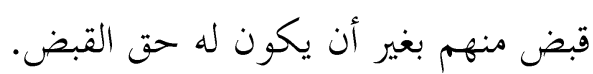

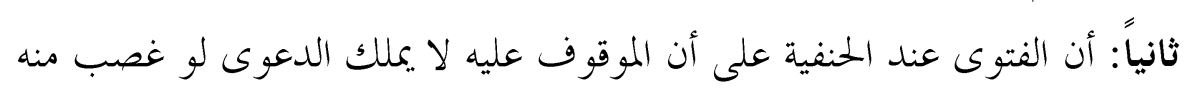

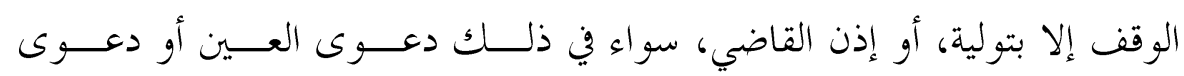

곡.

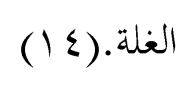

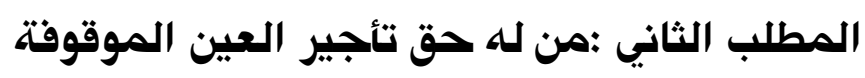

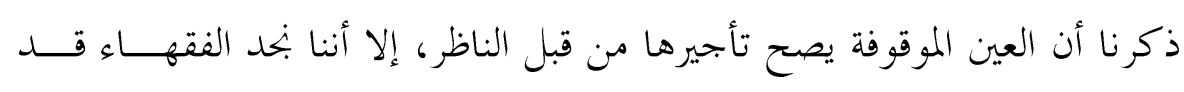

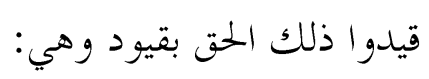

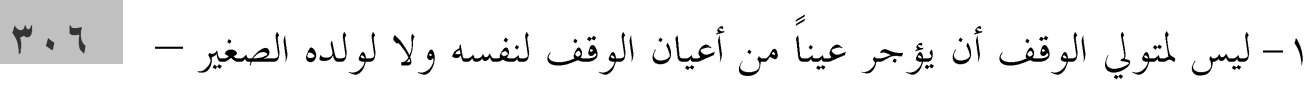

$\stackrel{5}{\stackrel{5}{5}}$

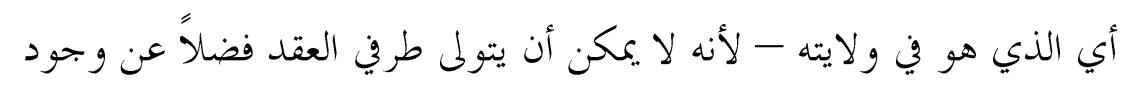

\section{الشبهة.}

ץ- كذلك لا يؤجر الناظر العين الموقوفة لمن لا يقبل شهادهم له، وهم أصــــله

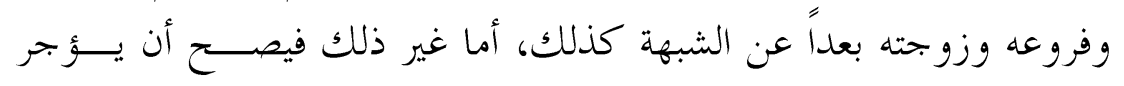

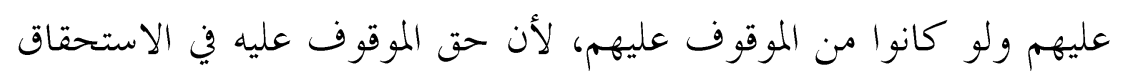
لا يتناف مع استئجار العقار الموقوف.

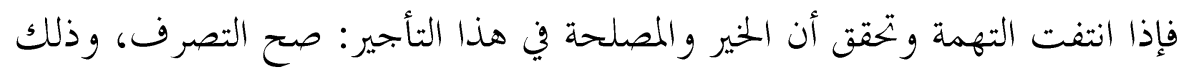

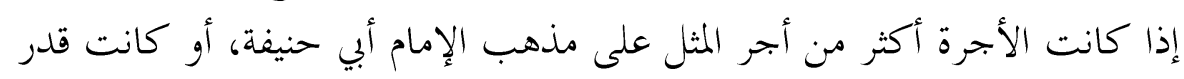

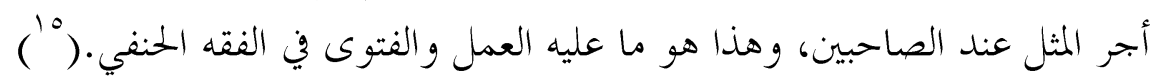


وخلاصة الأقو ال في المذهب الحنفي ثلاثة وهي:

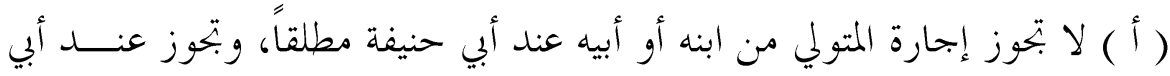

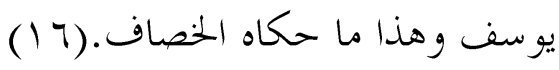

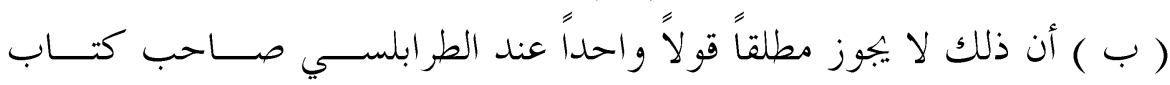

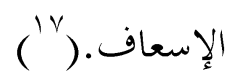

( ج ) بتوز عند أبي حنيفة إذا كانت بأكثر من أجرة المثل، وبتوز عند صـاحسبيه

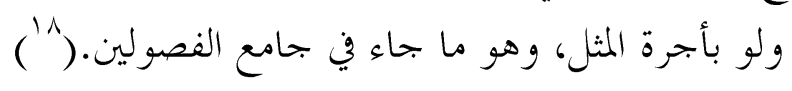

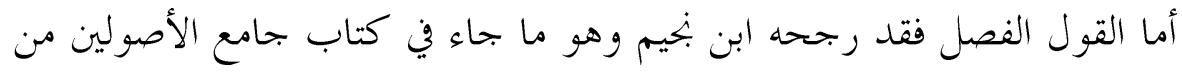

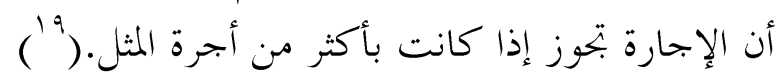

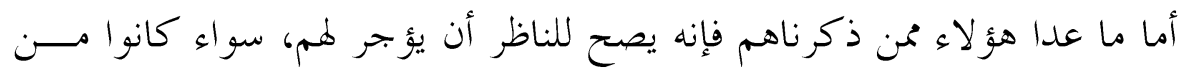

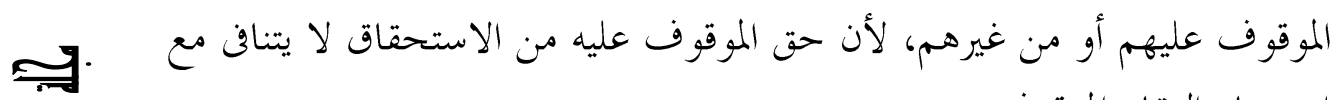
استئجار العقار الموقوف.

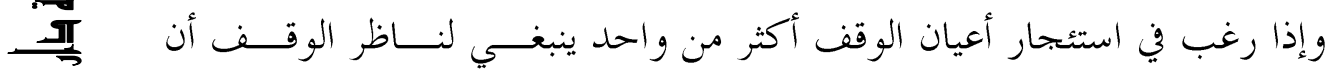

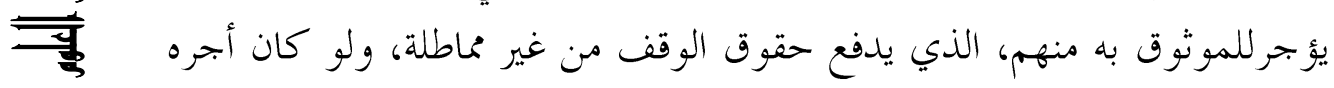

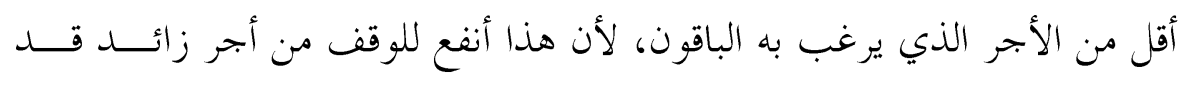

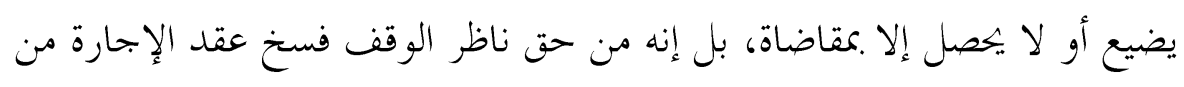

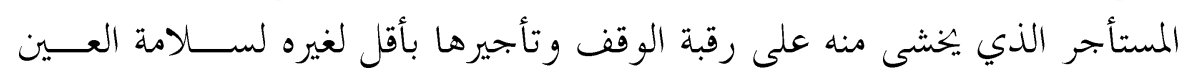

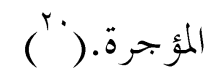

\section{المطلب الثالث : مقدار الأجرة}

يخالف الوقف الأعيان المملوكة في مقدار الأجرة، حيــث أن أن الأعيـان

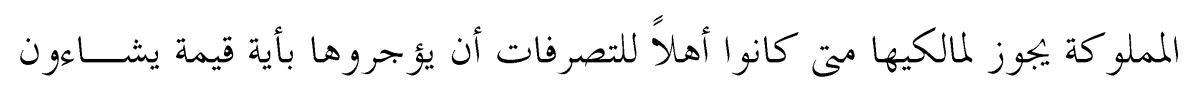

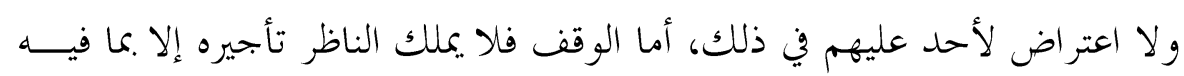

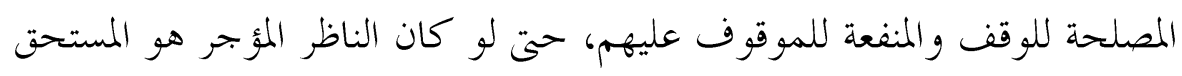

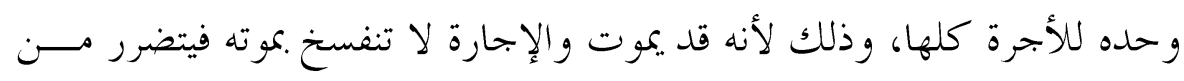


يستحق الوقف بعده بسبب نقص الأجرة، وقد يكون الوقف محتاجاً إلى العمـــارة فيلحقه الضرر كذلك، وعلى هذا لا تصح إجارة الوقف بأقل من أجر مثله بغبن فاحش.

فلو حصل مثلاً أن أجر العين إلى الموقوف بغبن فاحش، فالإجارة تقع هنا

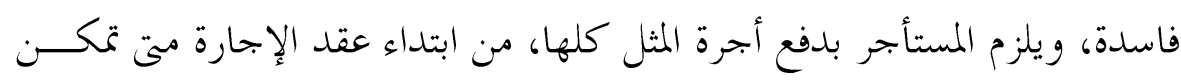

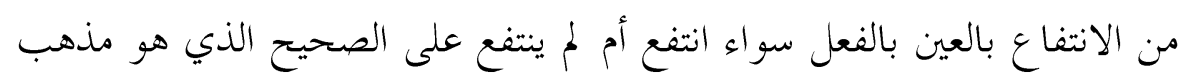

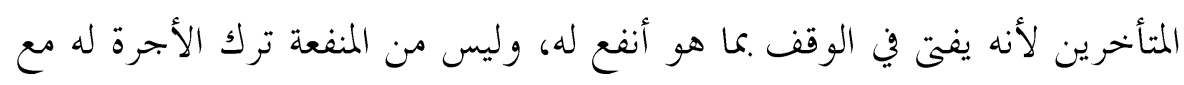
تمكنه من الانتفاع.

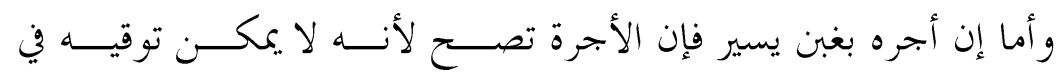
المعاملات، ويطالب بذلك الأجر في المدة المعينة في العقد.(Y) و إليك أقوال الفقهاء في تأجير العين الموقوفة بغبن فاحش:

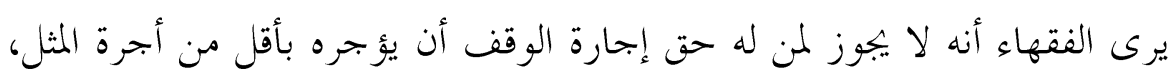
حتى لو كان المؤجر هو الناظر في حال كونه هو المستحق للأجرة كلها.

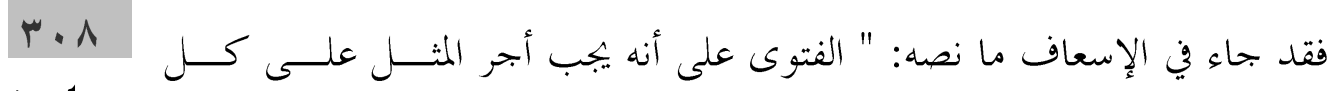

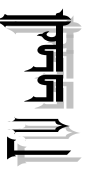
حال". ( و إنما منع الفقهاء ذلك لأنه قد يموت، والإجهــارة لا تنفســخ بموتـــه، فيتضـــرر المستحقون للوقف بعده بسبب نقص الأجرة، أو يتضرر الوقف حسـين يكـــون محتاجاً إلى عمارة. (rT) ويفرق الشافعية(؟)) والحنابلة(Y) بين أن يؤجر المتولي العين الموقوفة على غيره، و العين الموقوفة عليه. ففي الحالة الأولى: لا يجوز له أن يؤجرها بأقل من أجرة المثل. 
أما في الحالة الثانية: فإن له ذلك قياساً أولياً على صحة الإعارة منه، كما

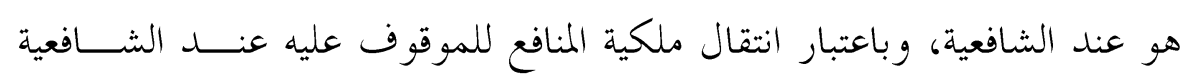
والحنابلة.

قال الخطيب الشربيني: " ومنافعه ملك للموقوف عليه يستوفيها بنفسـهـ

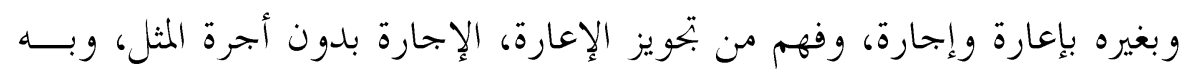

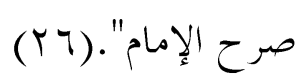

\section{حكم الإجارة إذا زادت الاجرة أو نقصت في هذه المدة:}

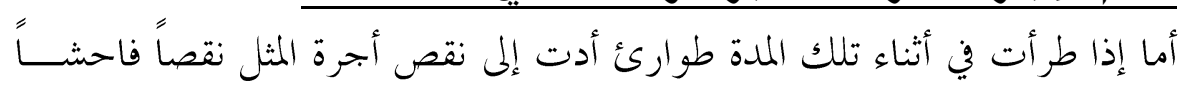

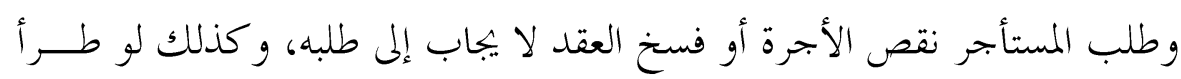

궉.

$r \cdot q$

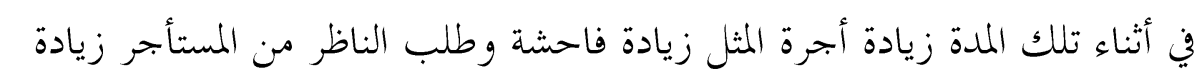

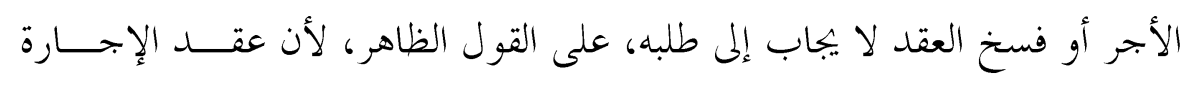

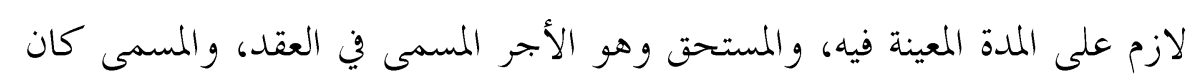

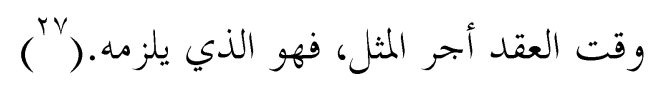
وإليك خلاصة ما ذكره الفقهاء من أقو ال:

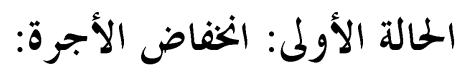

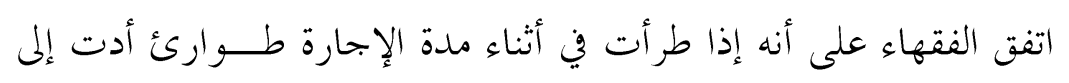

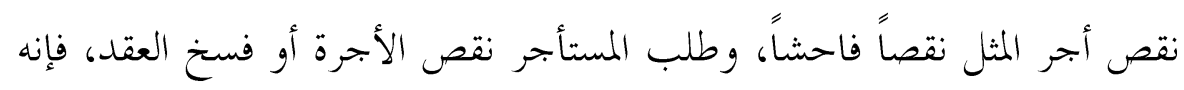

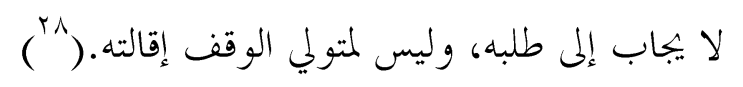

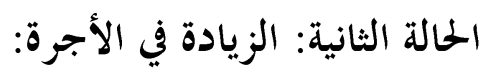

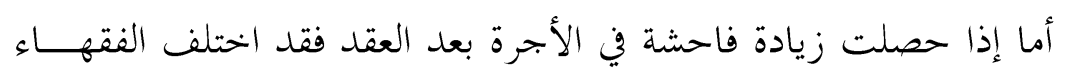

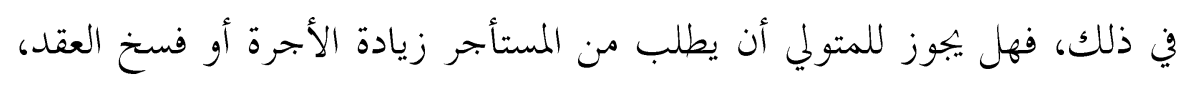
أم لا ؟ 
للفقهاء أيضاً أقو ال في هذه المسألة:

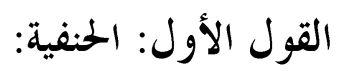

نستطيع أن نوجز آراء فقهاء الحنفية في قولين:

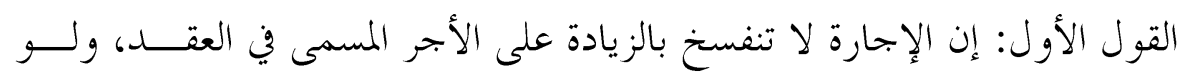
كانت هذه الزيادة فاحشة.

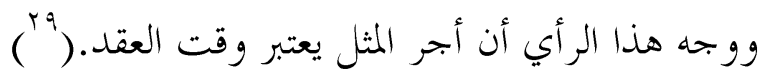

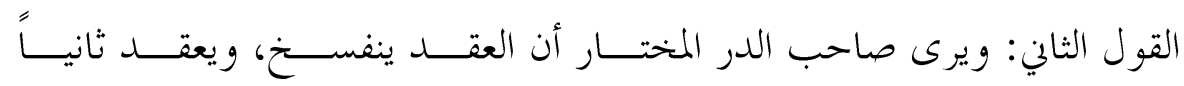

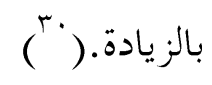

القول الثالي: المالكية والحنابلة:

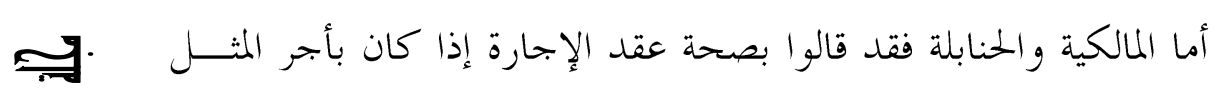

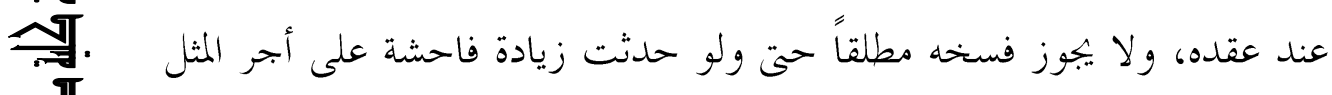

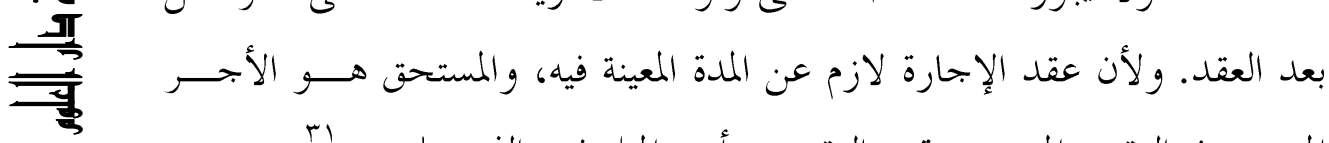

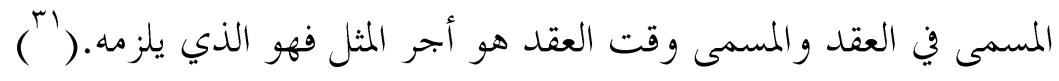

القول الثالث: الثافعية:

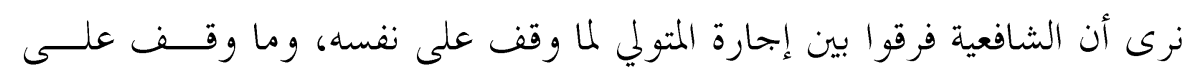
غيره:

فإذا أجر المتولي العين الموقوفة عليه فإن العقد يصح قطعاً ولو بدون أجر أجر المثل وهو كما لو أجر ملكه المطلق.

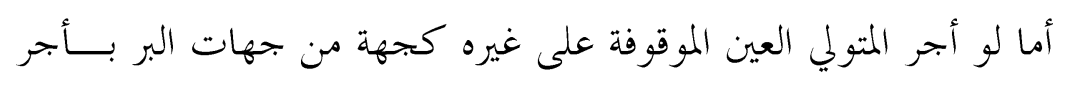

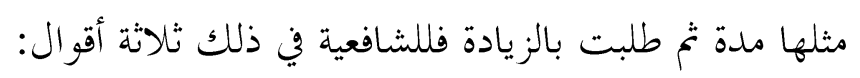

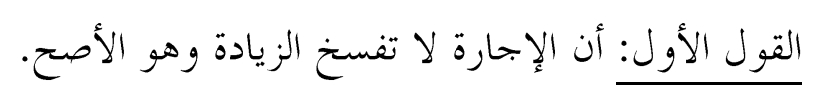




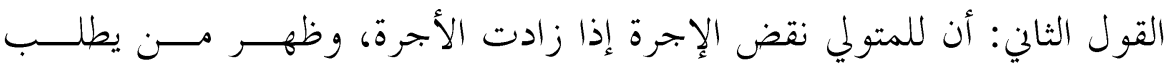

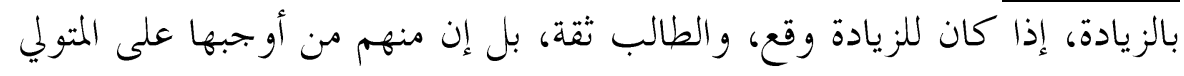

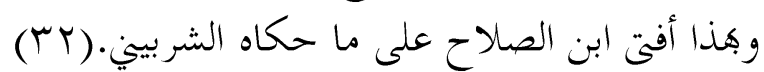

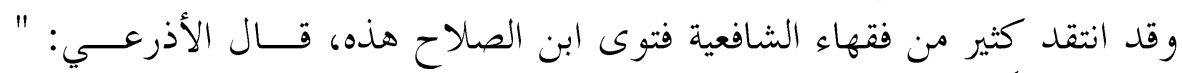

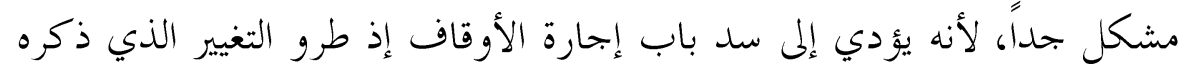

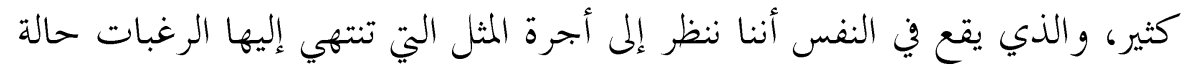

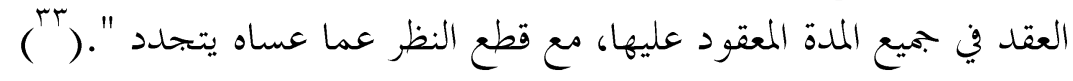

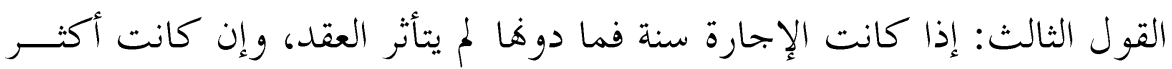

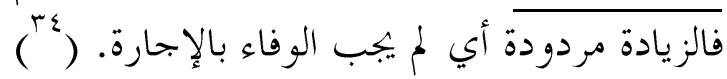

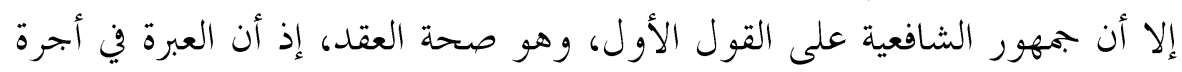

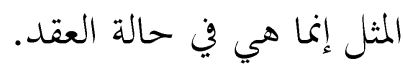

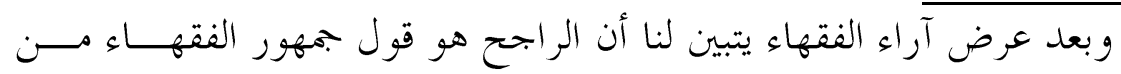
التوفيق بين الآراء

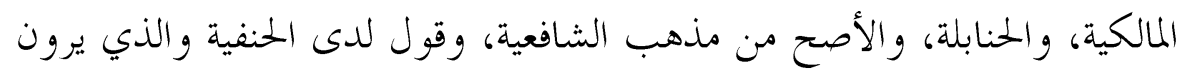

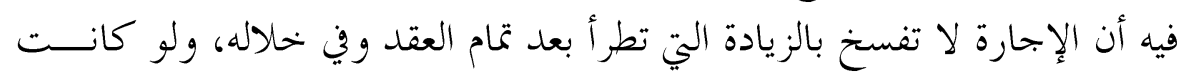

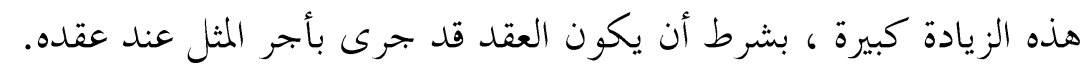

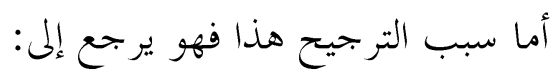

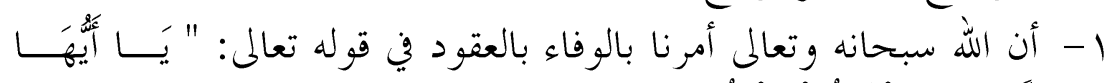

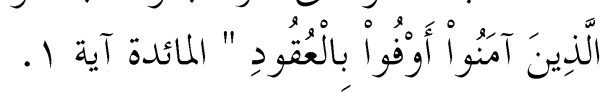

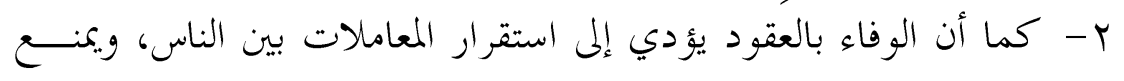
المشاحنة والخصومات.

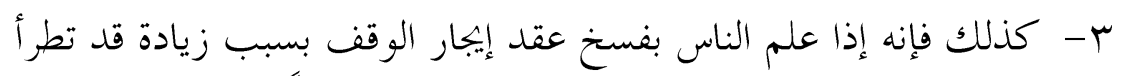

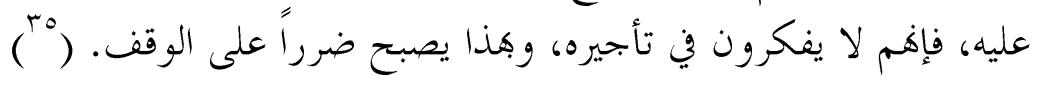




\section{المطلب الرابع : مدة إجارة الوقف}

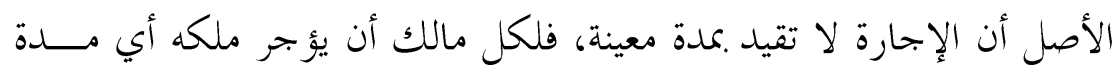

$$
\text { شاء، سنة أو عشر سنين، أو أكثر أو أقل. }
$$

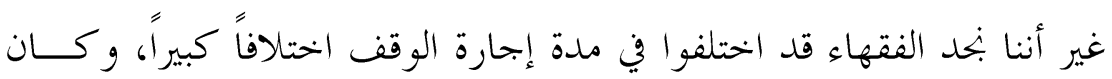

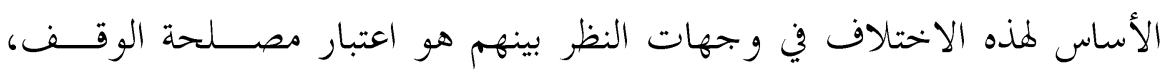

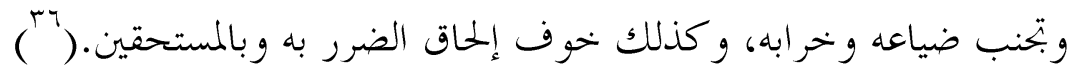

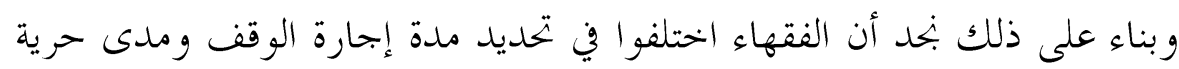

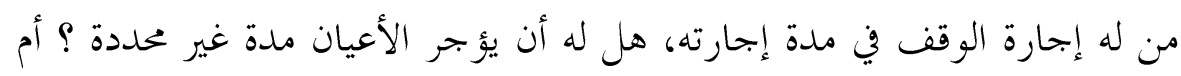

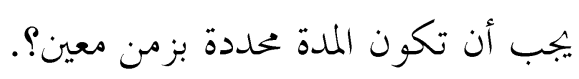

ज्ञ وقد انقسم الفقهاء في ذلك إلى قولين:

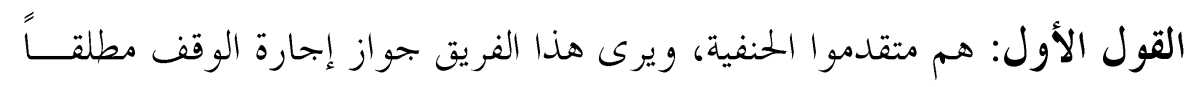
من غير تقدير للمدة مهما طالت.

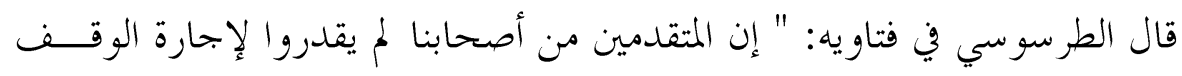

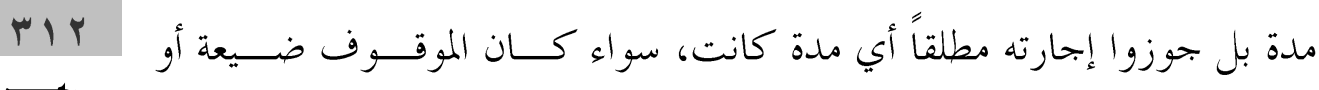

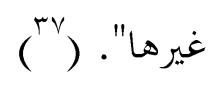

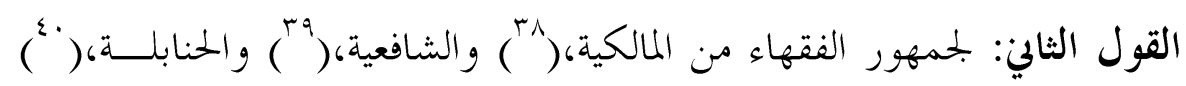

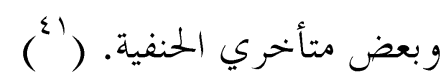
وهم يرون أن إجارة الوقف لا تصح مطلقاً، بل يجب تحديدها بمدة معينة.

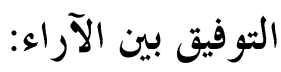

نرى ما ذهب إليه جمهور الفقهاء من عدم جواز إطلاق مدة إجارة الوقف وذلك

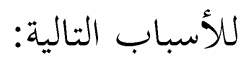


أ- إن أحوال الناس متغيرة ومتطورة، وقد يزيد ذلك في أجرة الوقف لأن

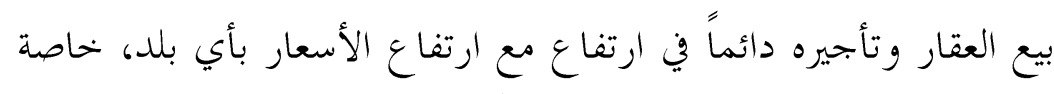

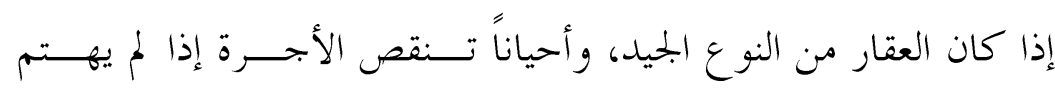

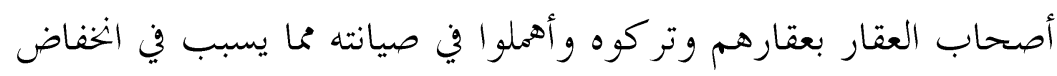

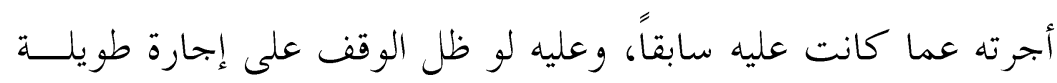

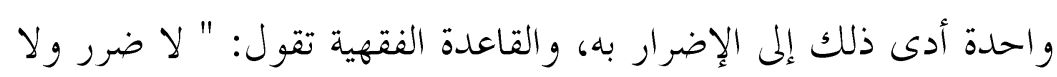

$$
\text { ضr }
$$

ب- ويترتب على ما ذكر في أن إطالة مدة الإجارة للوقف انــــراس لــهـ

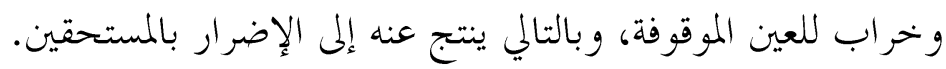

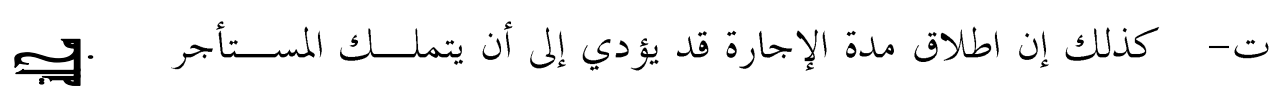

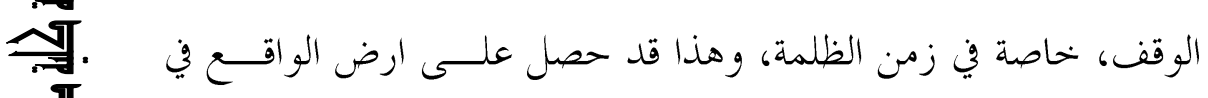

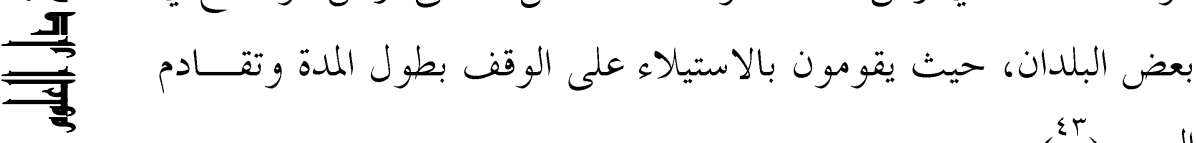

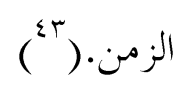

ذكرنا أن الراجح من الأقوال هو ما ذهب إلوف إليه جمهور الفقهاء القــائلين

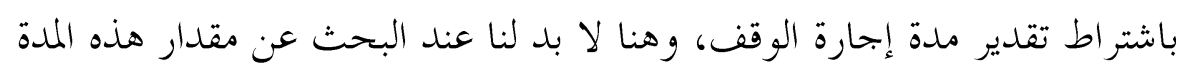

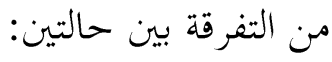
الحالة الأولى: أن يشترط الو اقف مدة الإجارة، فإذا اشترط الواقــف في صــك

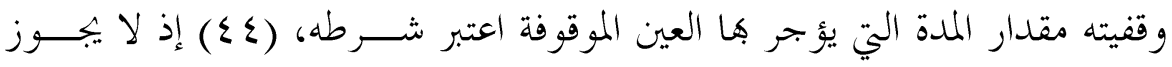

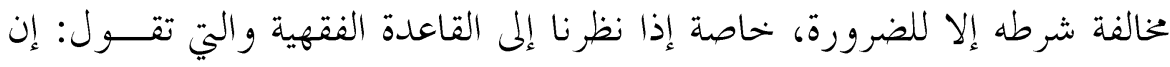

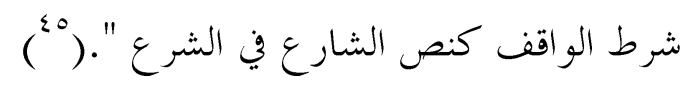


قال الخطيب الشربيني: " إذا شرط الو اقف أن لا يؤجر وقفه إلا سنة ونوها فإنه

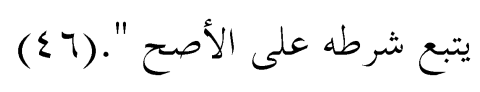

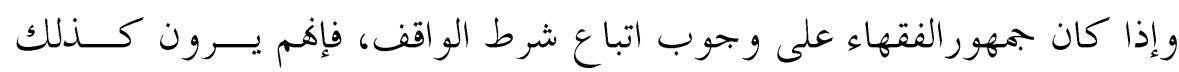

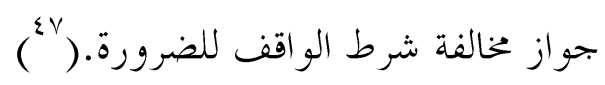

الحمالة الثانية: أن لا يشترط الو اقف وقتاً للإجارة.

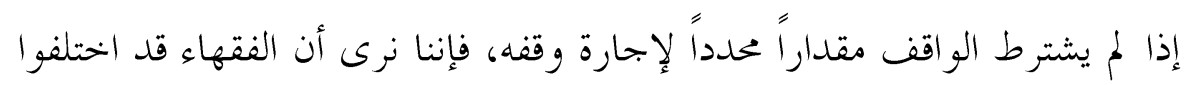

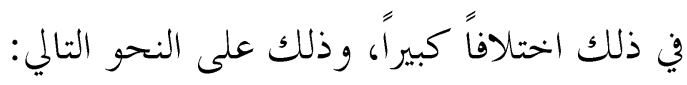

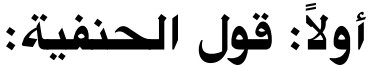

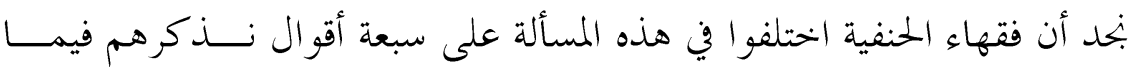

굴 يلي:

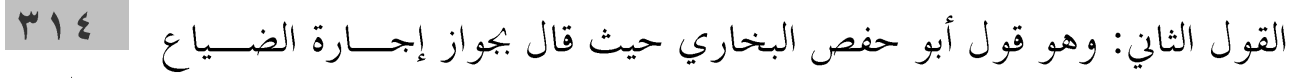

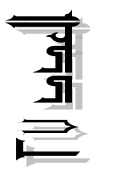

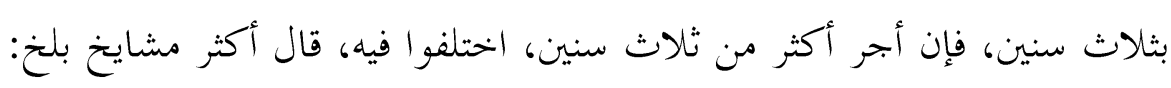
لا يجيوز.

القول الثالث: قول الشيخ أبو حفص الكبير، وعليه الفتوى، يجوز في الضــياع

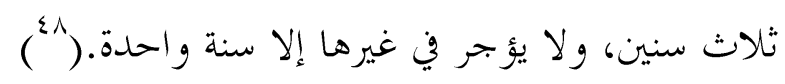

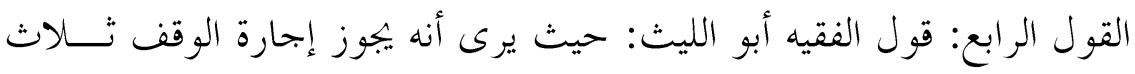

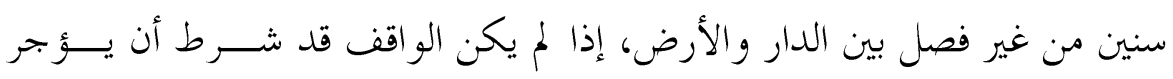
أكثر من سنة. 
القول الخامس: ذهب إلى هذا القول فريق من فقهاء الحنفية، وعليه فقد قــالوا

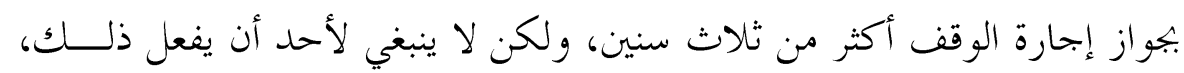

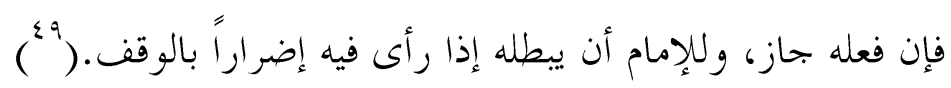

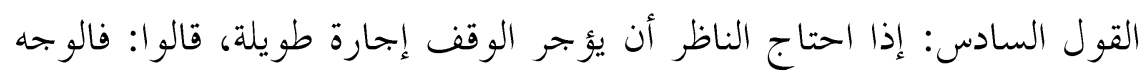

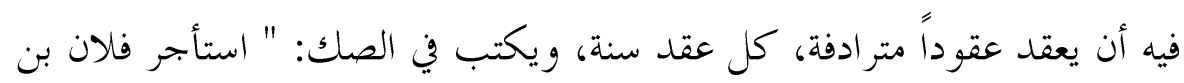

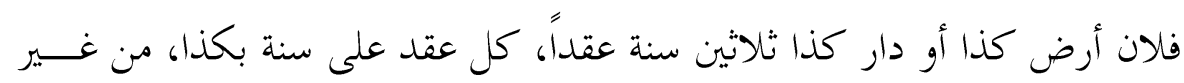

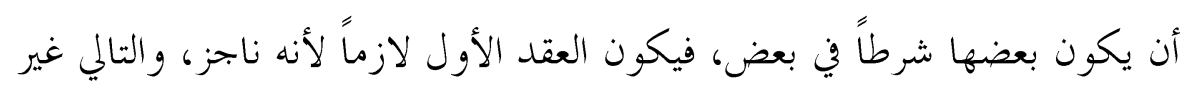

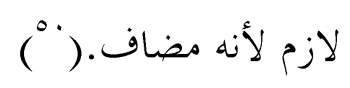

القول السابع: وهنا اتفق فقهاء الحنفية على جواز إجارة الوقف مدة طويلة إذا

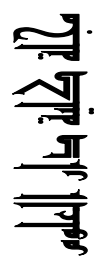
دعت إلى ذلك ضرورة، وكانت مصلحة الوقف بجانب ذلك.

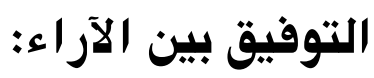

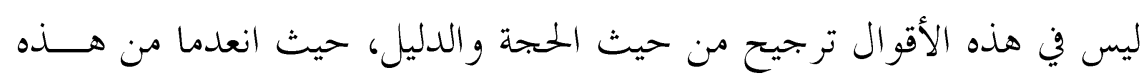

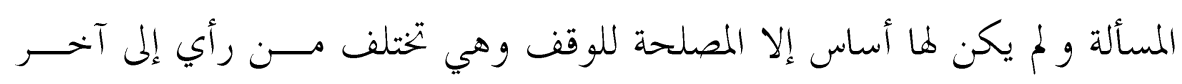

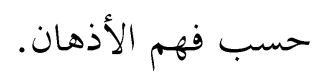

أما الذي نؤيده فهو قول الشيخ أبو حفص الكبير القائل بأن الأجارة في الضياع

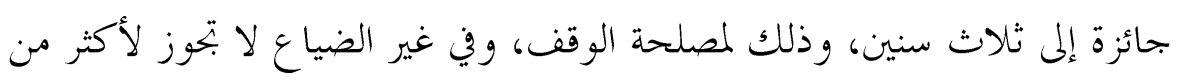

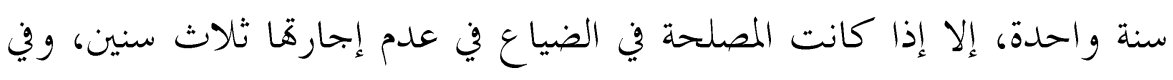

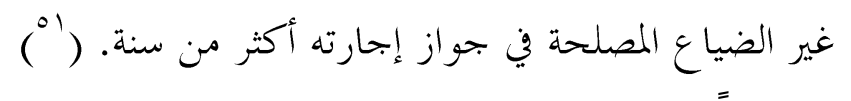

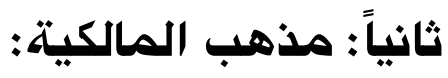

المالكية كغيرهم يقيدون إجارة الوقف بمدة معينة، إلا أفم يفرقون في ذلك بين

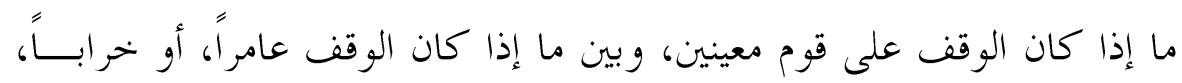


و بين ما إذا كانت العين أرضاً أو داراً، ولكل صورة من هذه الصور حكمى علــى النحو التالي: الصورة الأولى: أن يكون الموقوف عليهم معينين والمستأجر أجنبياً والعين عـــامرة فللمالكية في هذه الصورة قولان: القول الأول: وهو المشهور جوازه لسنتين، وهو مقتضى كلام ابن الحاجب، وابن

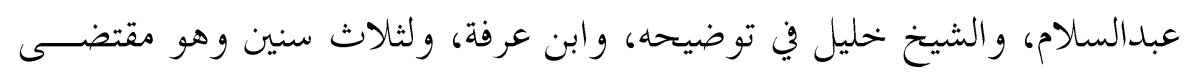
كام الشيخ خليل في مختصره و كلام شراحه. القول الثاني: جوازه لخمس سنين وهو قول ابن الماجشون على ما نقله ابن عرفـــة عن المتيطي ونقل عن الشيخ خليل في توضيحه جوازه لأربع سنين وحمس.

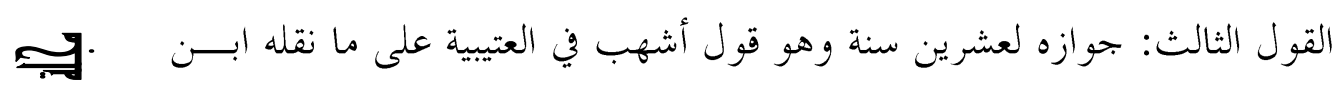

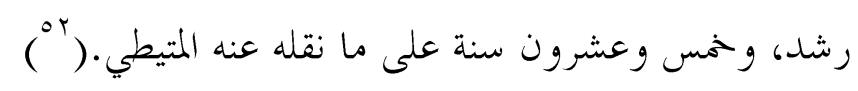

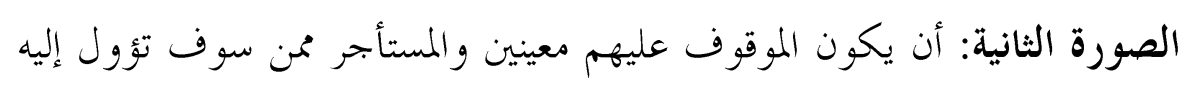
العين المؤجرة، فللمالكية في هذه الصورة أقوال ثلاث: القول الأول: ـ وهو المشهور ـ جوازه لعشر سنين وهو فعل الإمام مالك، ففي

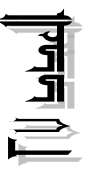
رسالة الحطاب ما نصه " فإن أكريت الدار الموقوفة لمن مرجعها له، فإنه يبجوز فيها العشر سنين ونهوها، لخفة الغرر

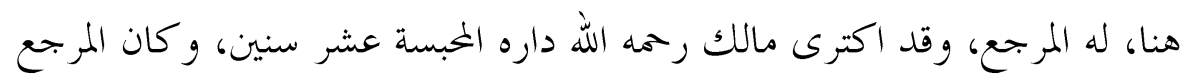
فيها له "( القول الثاني: جوازه لخمس سنين وهو قول ابن الماجشون على ما نقله ابن عرفة.

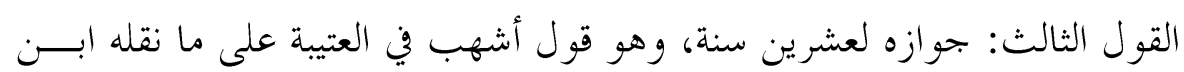

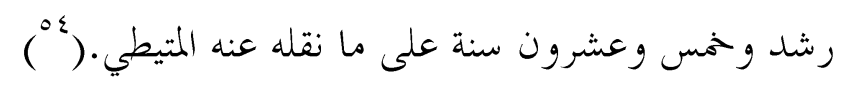


الصورة الثالثة: أن يكون الموقوف عليهم غير معيــنين ككــالفقر اء والمرضــى أو المساجد وغيرها من الجهات العامة و كذلك فإن للمالكية في هذه الصورة قولين:

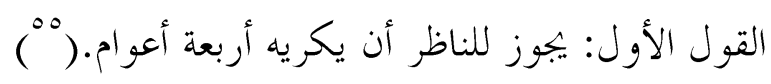

القول الثاني: وقد قال ابن عبدالسلام ومفاده: إنه إذا كان على الفقراء وشــــهـم

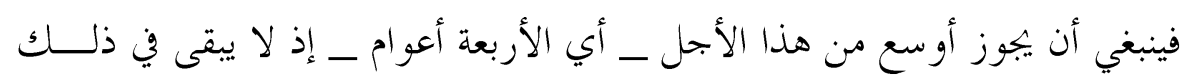
سوى اهدام الدار، وهذا الاحتمال لا يمنع من طول الأجل في الدار.

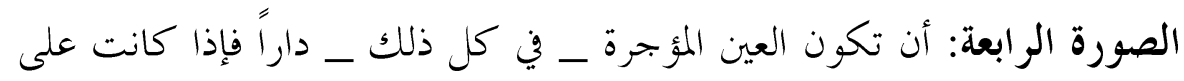

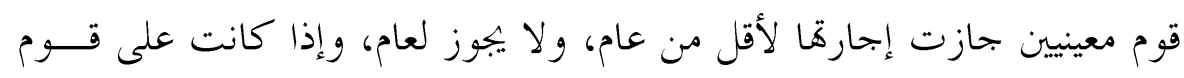
غير معينين لم بتز إجارةقا لأكثر من عام.

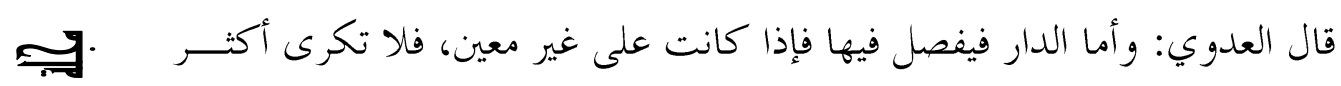
من عام، وأما إذا كانت على معين فلا تكرى عاماًاً . (

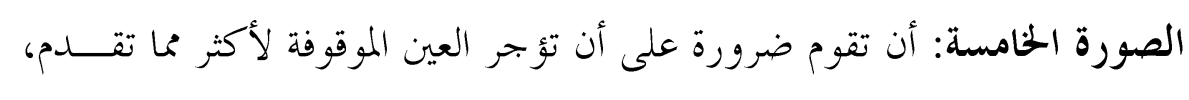
كما لو أهدم الوقف و لم يوجد ما يصلح به، فيجوز أن تؤجر الســنين الكــثيرة شرط بناء ما اكلدم.

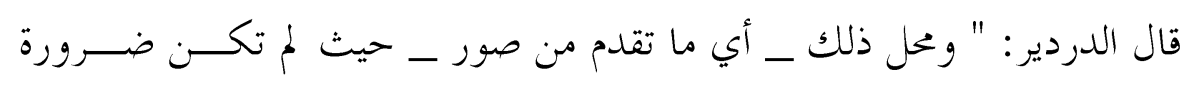

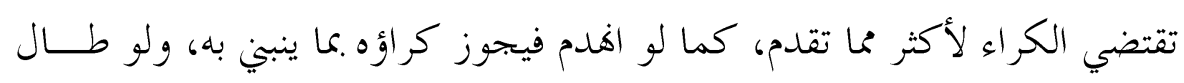

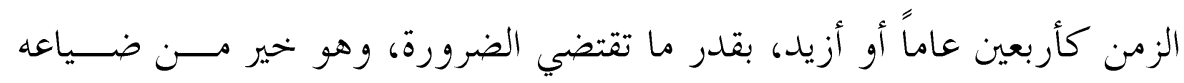

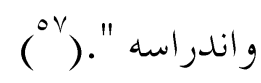
ثالثاً: قول الشافعية للشافعية ثلاثة آراء في تأجير الوقف:

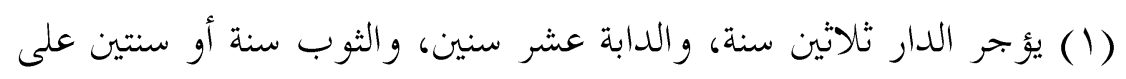
ما يليق به، والأرض مئة سنة أو أكثر. 


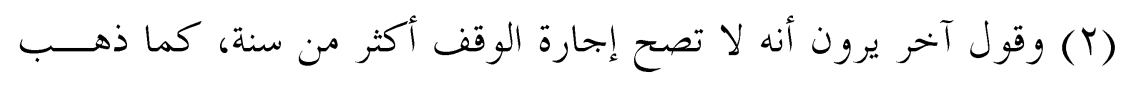
إلى ذلك الحنفية في بعض أقو الهم.

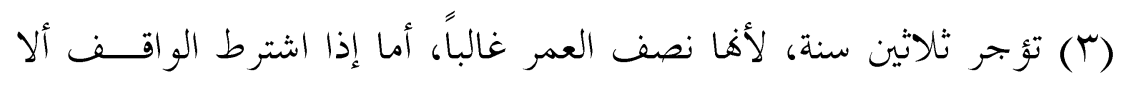

$$
\begin{aligned}
& \text { تؤجر اتبع شرطه.(^) } \\
& \text { رابعاً: قول الحنابلة: }
\end{aligned}
$$

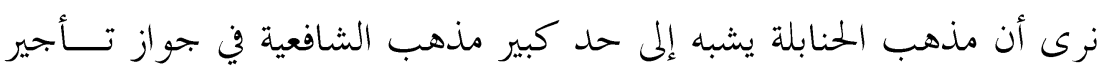

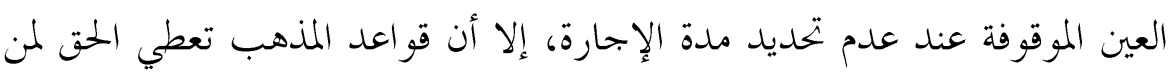

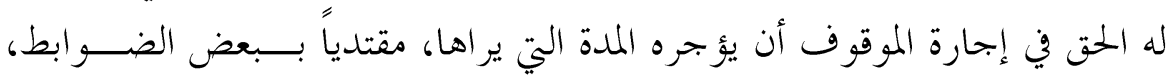

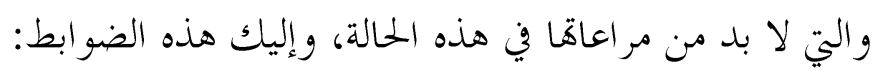

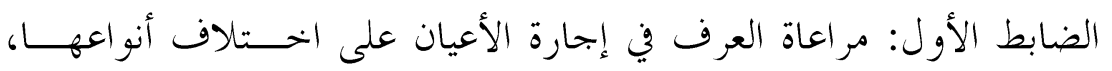

$$
\text { وطرق الانتفاع ها، كالدور والبساتين والأراضي الزراعية. }
$$

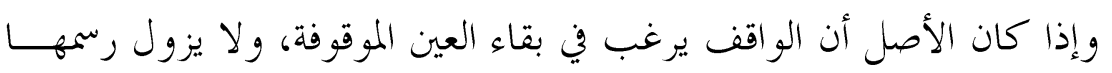

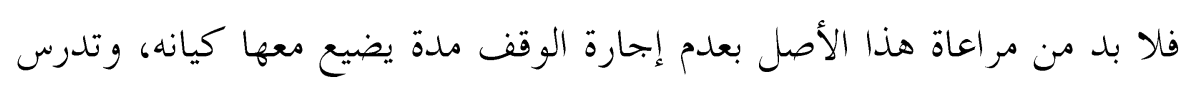
معالمه، وتضيع منافعه.

الضابط الثاني: أن الحنابلة أجازوا مخالفة شرط الواقف عند تحديد مدة الإجارة إذا كانت هذه المخالفة اقتضتها ضرورة، أو لتحقيق مصلحة راجحة للوقف. إذ القاعدة عندهم أن الشروط إنما يلزم الوفاء هـا إذا لم تقض إلى الإخهـلال

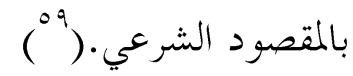

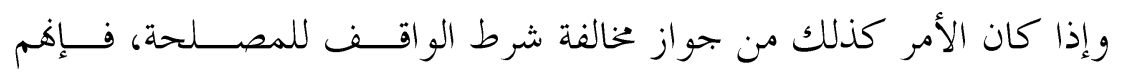

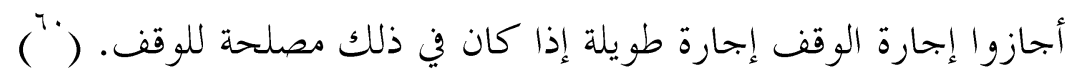

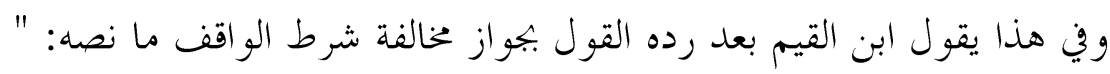

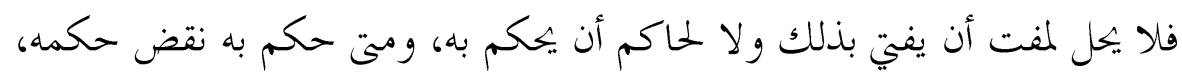

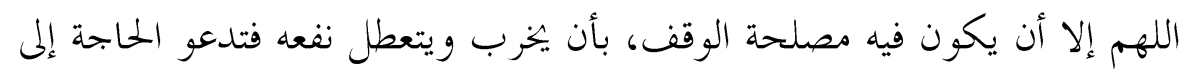




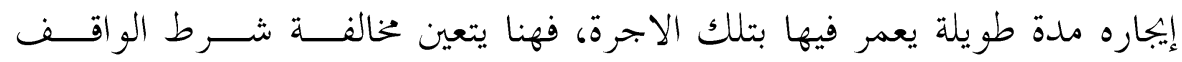

$$
\begin{aligned}
& \text { تصحيحاً لو قفه واستمر ارا لصدقته" (") } \\
& \text { التوفيق بين الآراء: }
\end{aligned}
$$

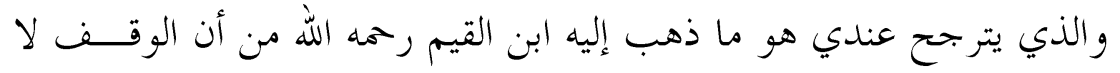

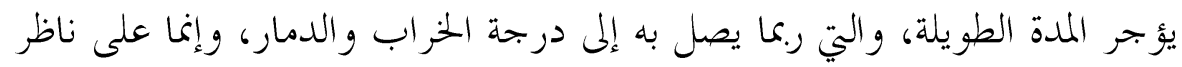

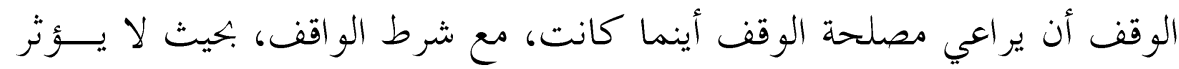

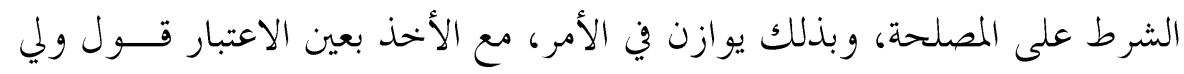

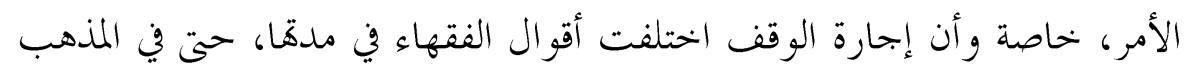

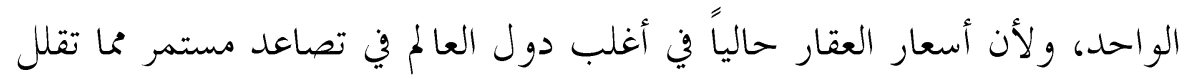
من قيمة ريع العين الموقوفة المؤجرة لمدة طويلة، وعليه أرى ألا تؤجر العين الموقوفة

أطثر من خمس سنين.( )

\section{المطلب الخامس : انتهاء مدة الإجارة}

هناك عدة أسباب تنتهي فيها مدة إجارة الوقف، وسأذكرها بالتفصيل الآتي:

\section{أولاً: موت العاقدين:}

الحكم العام عند الحنفية أن عقد الإجارة ينتهي .كموت العاقدين أو أحدهما.(") غير أن عقد إجارة الوقف لا ينتهي ولا يفسخ.موت المؤجر سواء كان هو الواقف

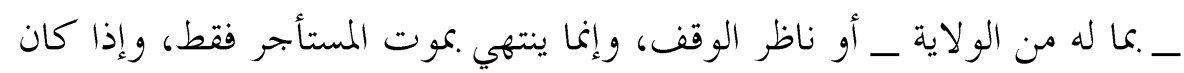

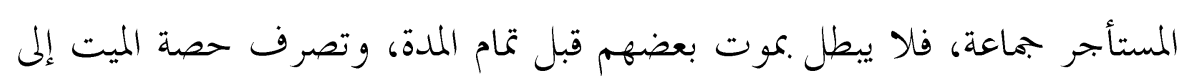
ورثته. وذلك لأن المؤجر في الوقف ليس مالكاً للعين، ولا لمنفعتها و العقد لم يــتم لــه، فموته لا يغير حكمه. وأما المستأجر: فالعقد وقع له، والأجر ملزم من ماله، ولو بقي العقد بعد موتــه، لاستحقت الأجرة من مال غيره، وهذا خلاف موجب العقد. 
والحنفية يجعلون هذا كما لو أجر القاضي الدار الموقوفة ثم عزل قبل انقضاء المــــة

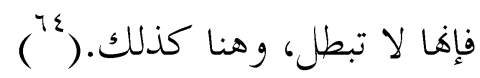

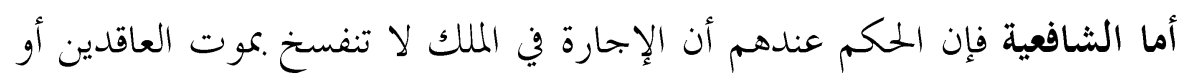

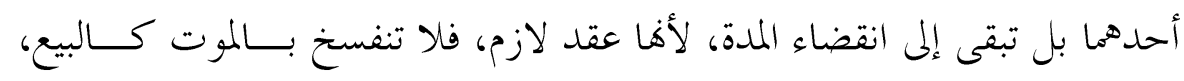

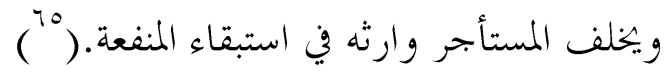

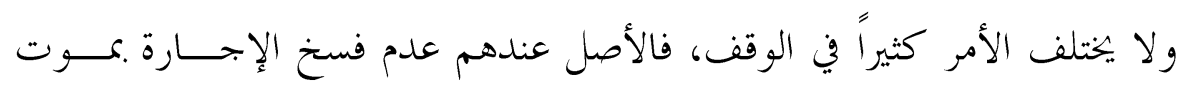
الناظر . جاء في مغني المتاج ما نصه: " ولا تنفسخ أيضاً. موت متولي الوقف من حاكم أو

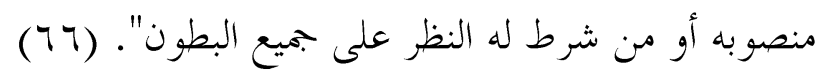
국.

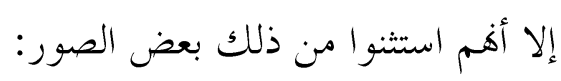

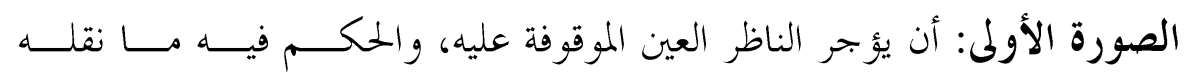
الشيرازي: " فإن أجر وقفاً عليه ثم مات ففيه وجهان:

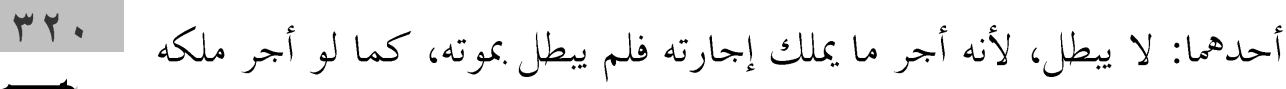

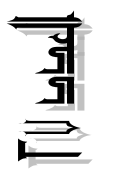

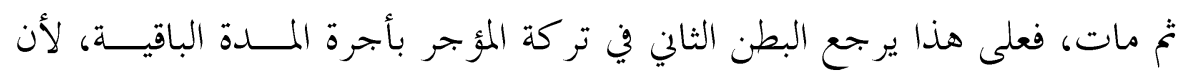

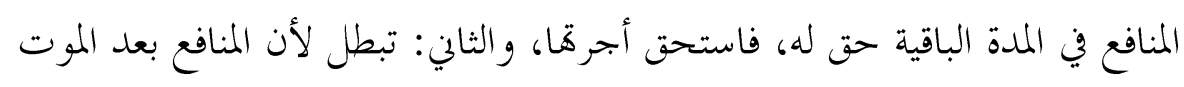

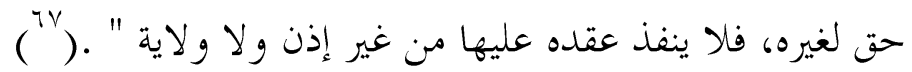

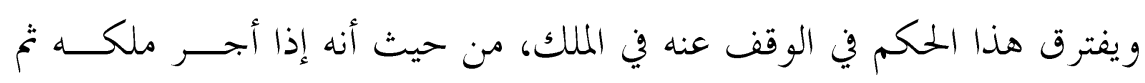

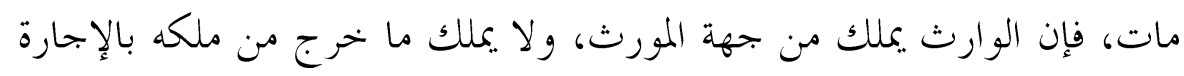
فلا يبطل العقد. أما في الوقف فإن البطن الثاني، يملك غلة الوقف من جهة الوقف فلا ينفذ عقد الأول عليه. 
الصورة الثانية: أن يكون المؤجر هو البطن الأول من الموقوف عليهم، فإذا أجســ

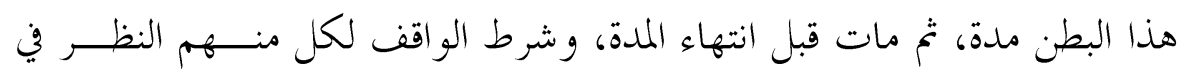

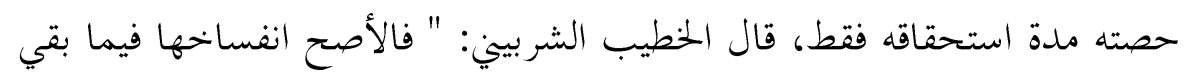

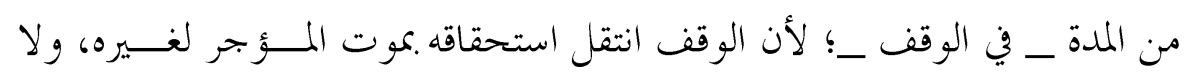

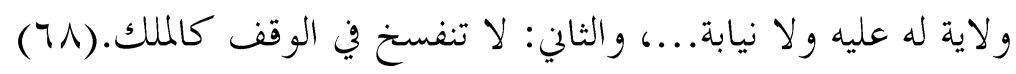
ومثل البطن الأول في هذا جميع البطون.

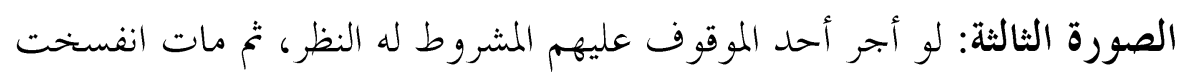

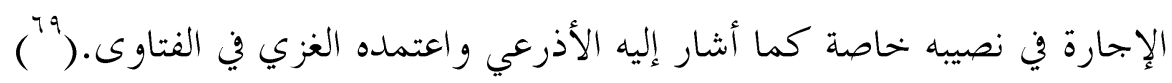

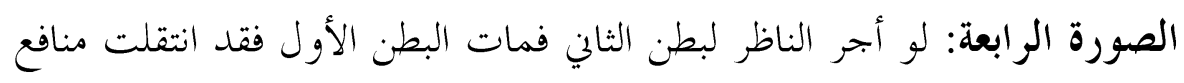

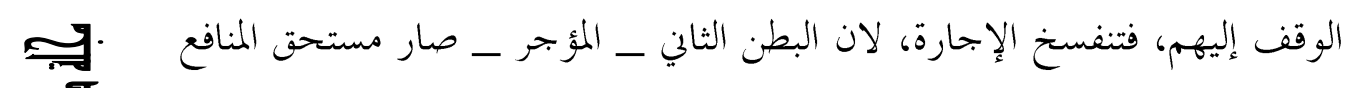

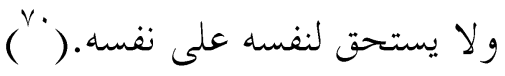

والمالكية والشافعية يفسخون الإجارة بموت الناظر إذا كان من جملة المستسـتحقين

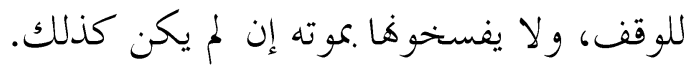
قال الدسوقي في إجارة الناظر: " المراد بالناظر في كام إنام المصنف من كان من جملة

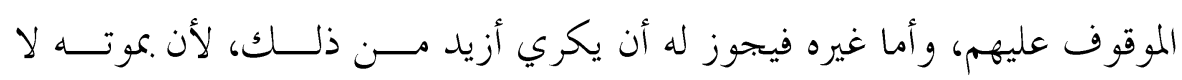

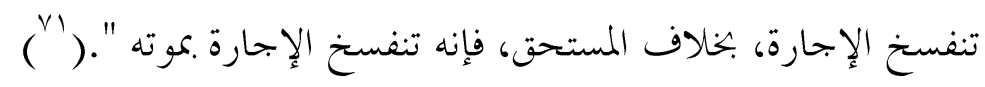
أما ما يترتب على انتهاء مدة الإجارة:

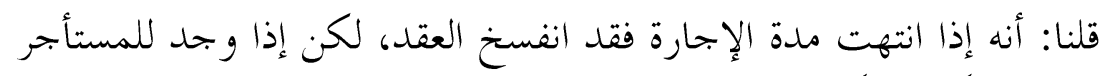

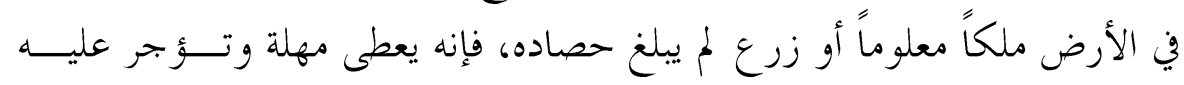

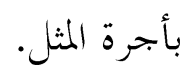
أما إذا كان في الارض ملك لهن ليس له هاية معلومة كالبنيان فما العمل؟. هنا يجب أن نفرق بين حالتين: 
الحالة الأولى: أن يكون الناظر قد أذن للمستاجر بالبناء وانتهت المدة، فتترك

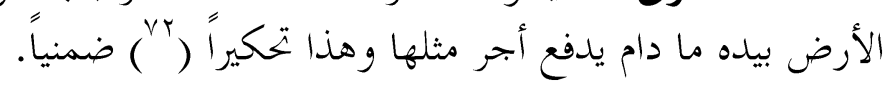

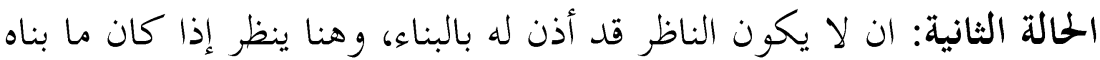

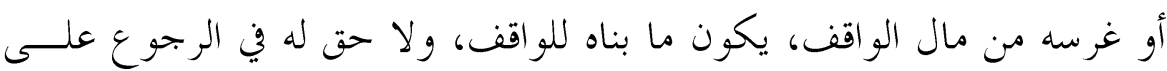

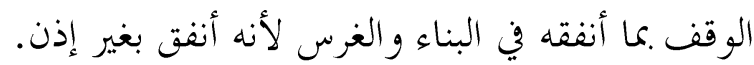

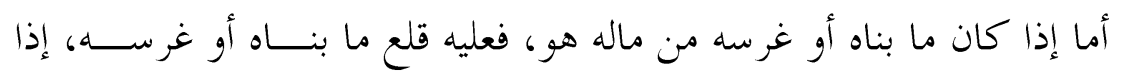

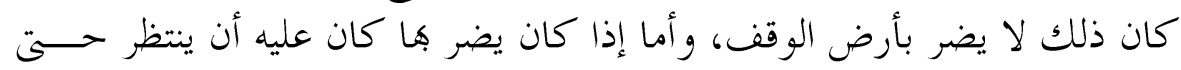

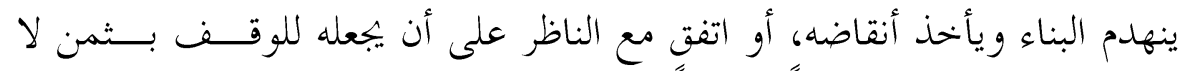

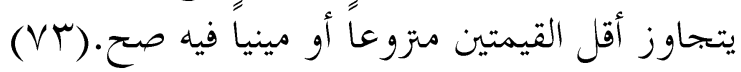

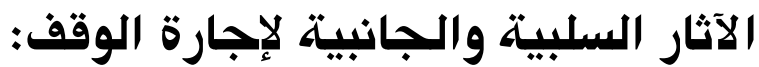

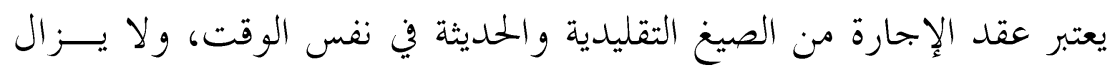

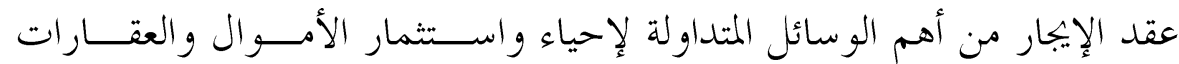

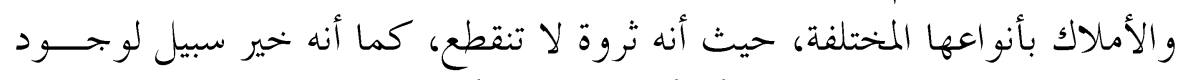

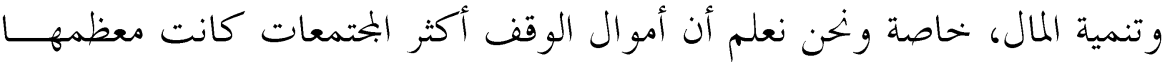

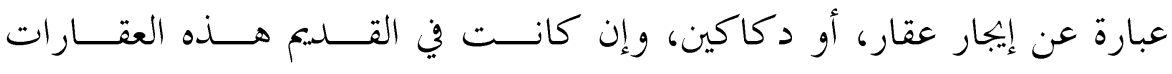

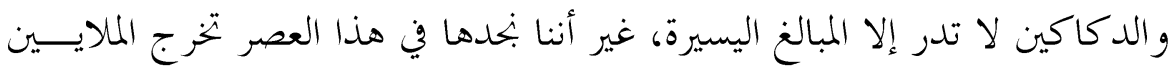

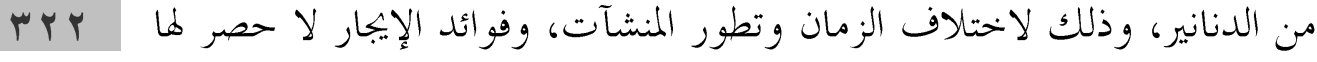

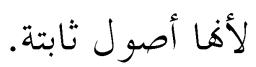

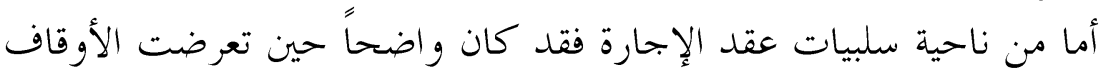

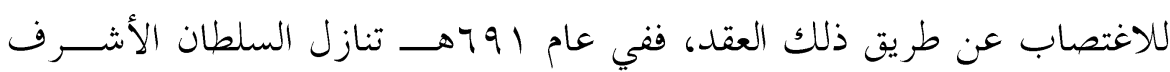

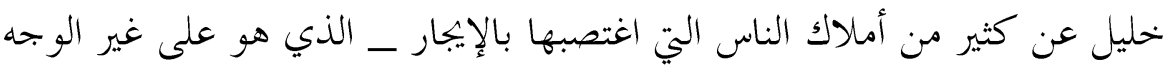

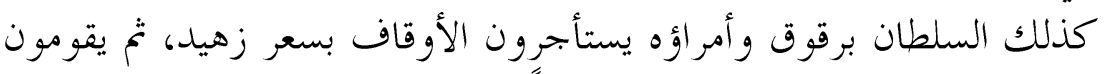

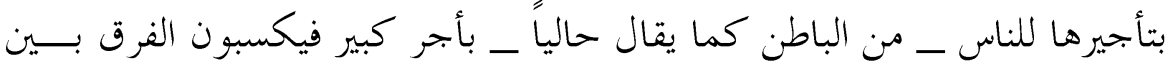

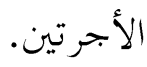

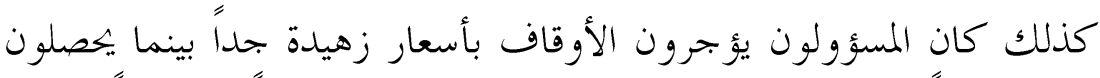

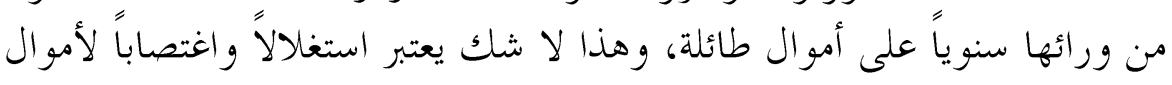

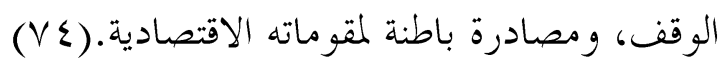




\section{المبحث الثاني \\ الوقف ذو الإجارتين \\ تعريف عقد الإجارة ذو الإجارتين:}

نعي بالوقف ذي الإجارتين: مستغلات الوقف المــؤجرة بإجـــارتين معجلــة

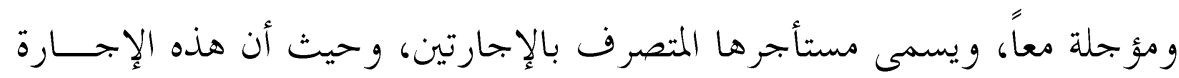

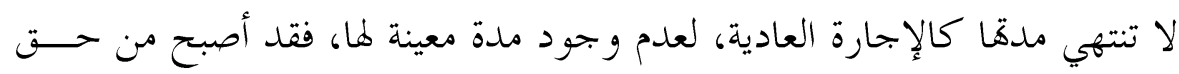

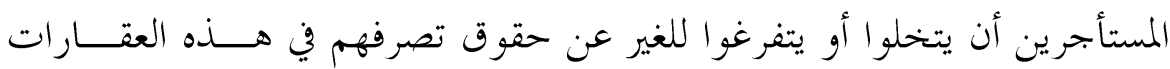

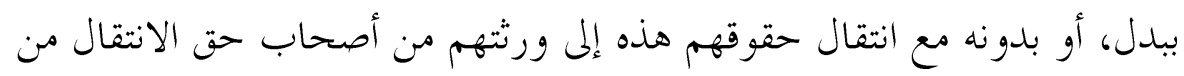

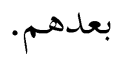

وعلى هذا يكون في هذا القسم من الموقوف أحيانــاً مســتأجر ان، أحســها

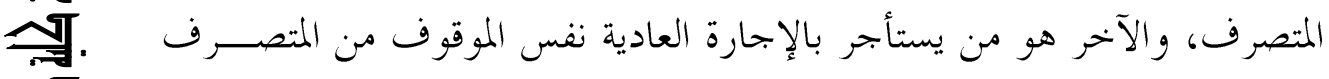

$\frac{\pi}{3}$

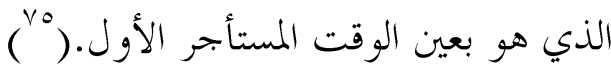 \\ التكييف الثرعي لعقد الإجارتين:}

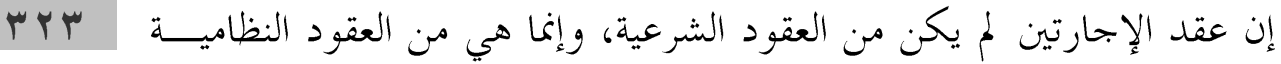

$\stackrel{5}{5}$
굴

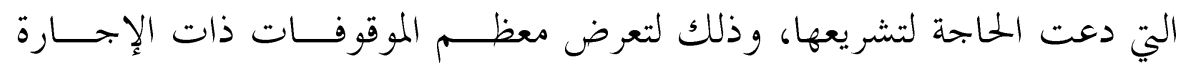

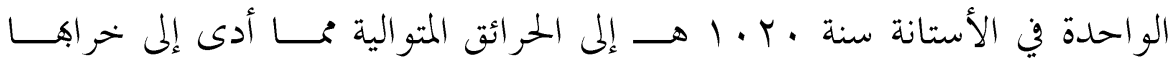

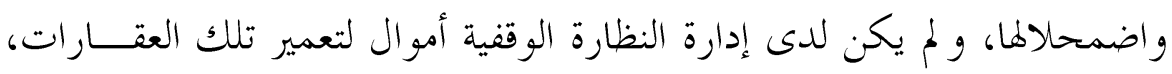

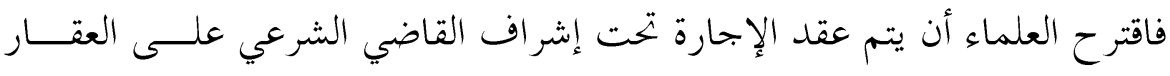

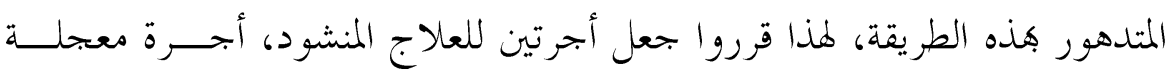

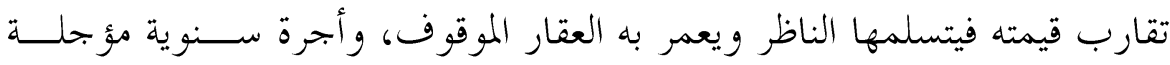
ضئيلة يتجدد العقد كل سنة، وذلك لعدم وجود ريع في الوقف لإعادة تعمير تلك الموقوفات، ومنأهم الشروط الواجبة لربط تلك الموقوفات بالإجارتين: 
1- زوال المنفعة من الموقوف بناء على كونه خر اباً لا بمكن استغلاله.

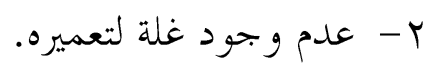

r- كذلك تعذر إيهاره مدة طويلة تعميره واستغلاله.

$$
\text { ع - أن لا يتيسر استبداله. }
$$

ه- ولا بد من إذن القاضي وصدور إرادة ملكية بذلك.

\section{أما أحكام الوقف ذو الإجارتين:}

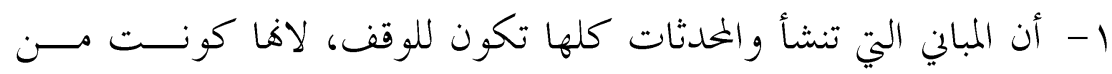

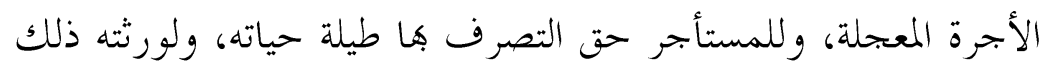

$$
\text { الحق بعد و وفاته. }
$$

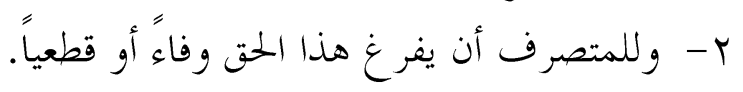

궉.

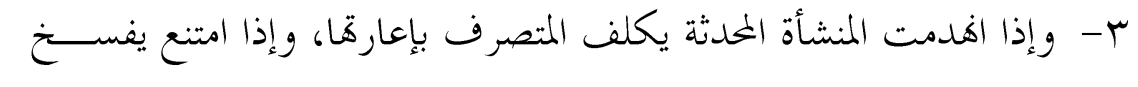

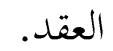

$\frac{\frac{\pi}{3}}{=\frac{4}{3}}$

rrs

ع - لو مات المتصرف بالإجارتين في دار الوقف للوقف مثلاً و لم يترك أحداً

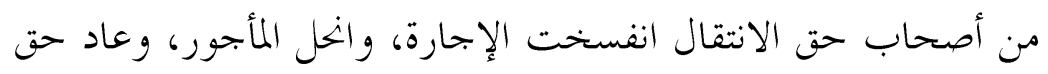

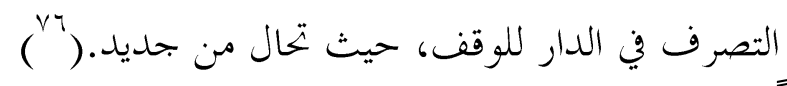

\section{ثالثاً: واجبات المستأجر:}

وي حالة ما إذا تم الاستئجار فعلى المستأجر أن يدفع المبلغ المقطوع، والمرتسب

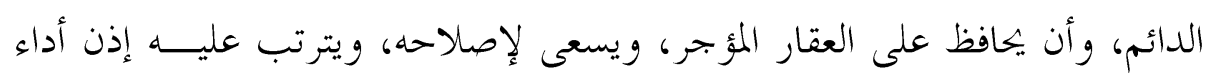

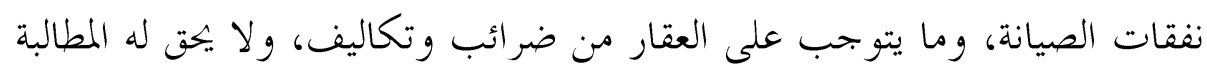
بالنفقات التي يدفعها ولا بقيمة التحسين الذي يجدثه فيه.

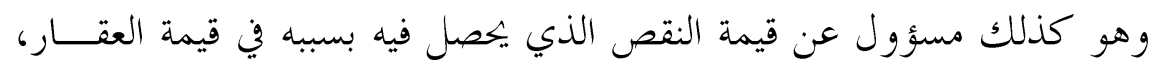

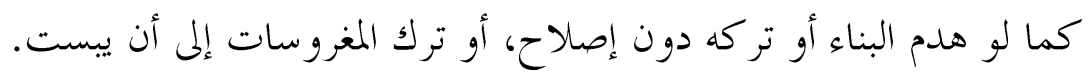




\section{رابعاً: مدة انتهاء عقد الإجارتين: \\ ينتهي عقد الإجارتين في الأحوال الآتية:}

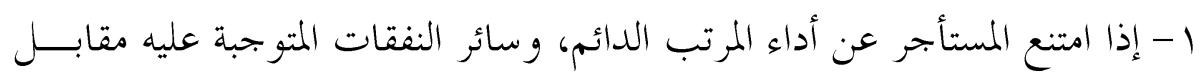

تمتعه بالإجارة، فيمكن عندئذ السعي إلى نزع ملكيته بالطرق القانونية.

Y- إذا بقي المستأجر عشر سنوات دون أن يستعمل حقه على العقار الموقوف.

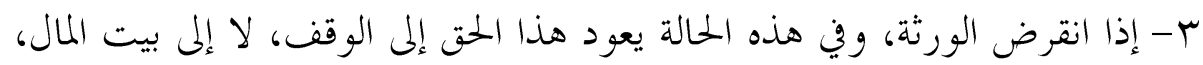

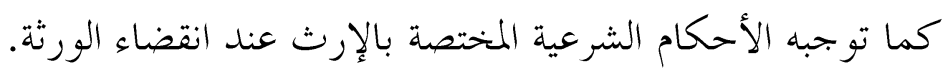

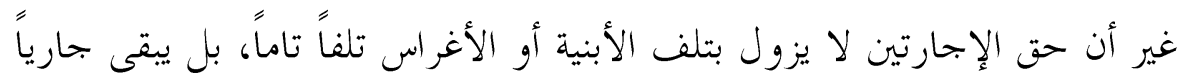

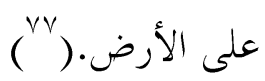

궉

\section{خامساً: الآثار السلبيتة لهذه الصيغتة:}

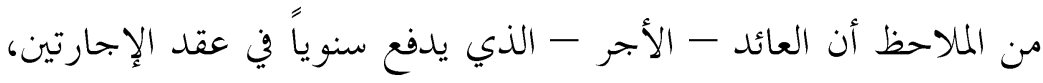

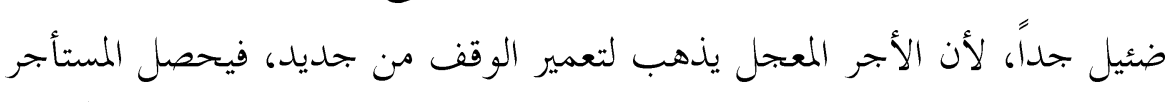

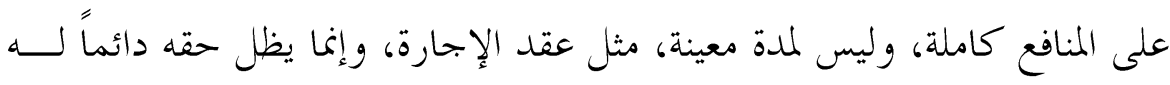

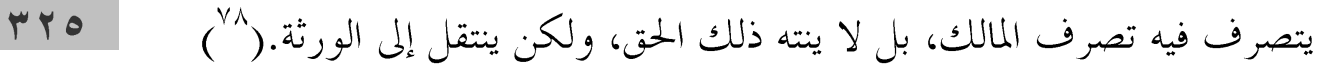

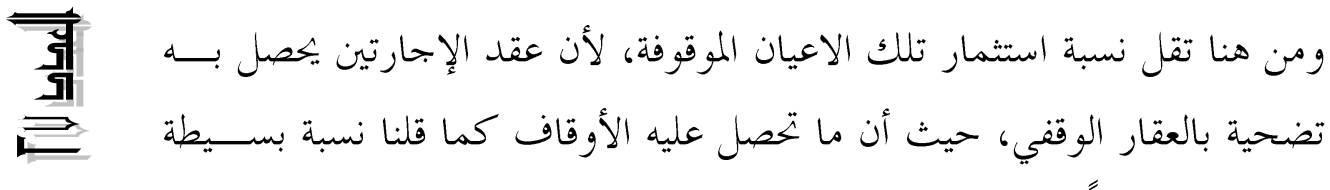

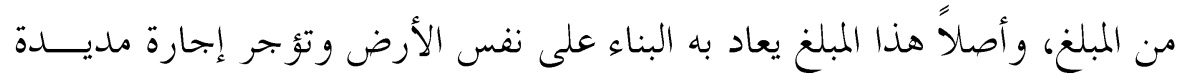

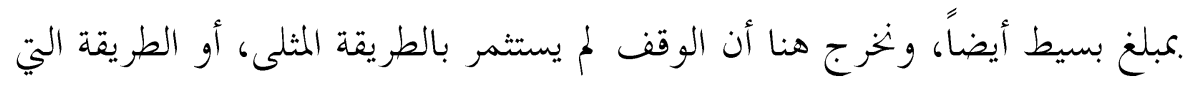

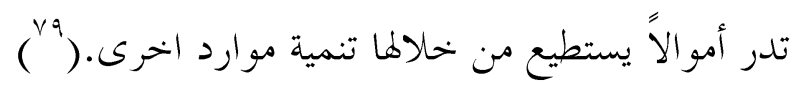




\section{المصادر والمراجع}

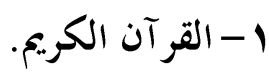

Y- ابن حجر الميتمي، أحد بن محمد بن علي، تحفة الختاج في شرح المنهاج، دراسة

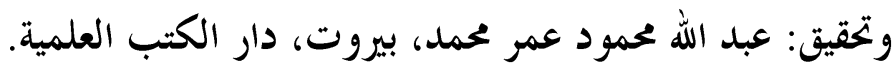

ب- ابن عابدين، محمد أمين بن عمر، رد الختتار على الدر المختار، الآستانة، المطبعة

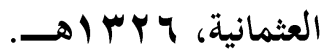

ـ - ابن قيم الجوزية، محمد بن أبي بكر، إعلام الموقعين عن رب العالمين، تحقيق: طه

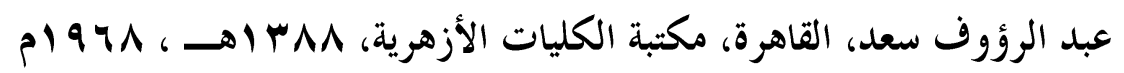

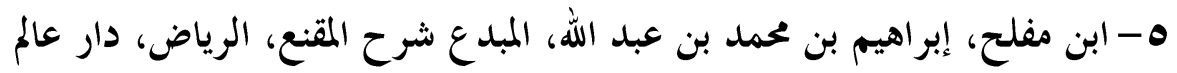

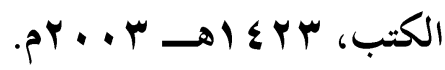
צ- ابن منظور، محمد بن مكرم الأفريقي المصري، لسان العــرب، بــيروت، دار صادر، ط 1.

V- ابن نجم الحنفي، البحر الرائق شرح كتز الدقائق، مصر، المطبعة العلمية، ط ا

^- أبو البقاء بهرام الدميري، الشرح الكبير، الرباط، مخطوط بالحز انة الحســينية،

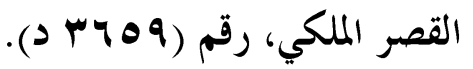

9- أحمد إبراهيم بك، أحكام الوقف والمواريــث، القــــرة، المطبعـة الســلفية،

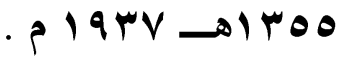
• 1 - أحمد إبراهيم بك، المعاملات الشرعية الماليــة، القـــرة، المطبعـة الفنيسة، . 1ا - أحد التميمي، الفواكه العديدة في المسائل المفيدة، دمشق، المكتب الإسلامي،

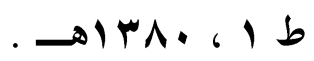




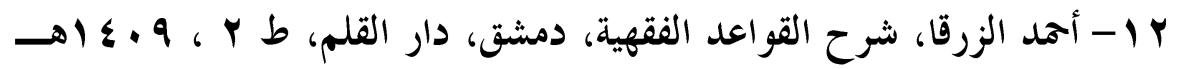
. pl919

با ا - الأنصاري زكريا بن محمد بن زكريا، أسنى المطالب في شرح روض الطالب،

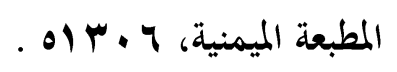

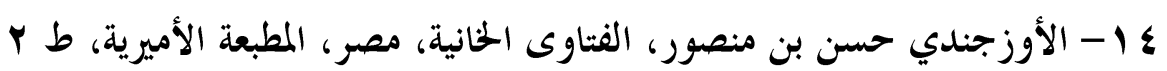

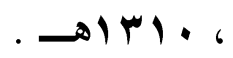

هـ - البهوتي، منصور بن يونس، كثاف القناع عن متن الإقناع، مصر، المطبعـة

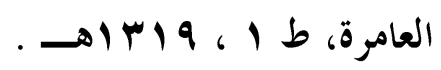

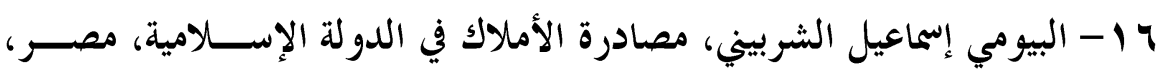

ज्ञ

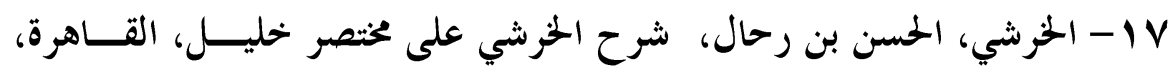

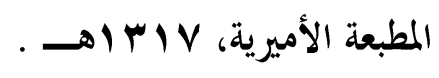

11 ا- الخصاف أحمد بن عمرو، كتاب أحكام الأوقاف، القاهرة، مكتبــة الثقافــة الإسلامية.

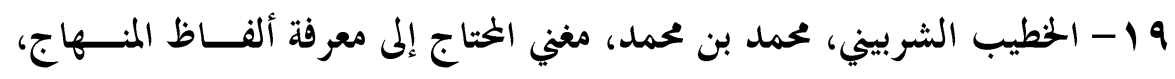
مصر، مطبعة مصطفى محمد.

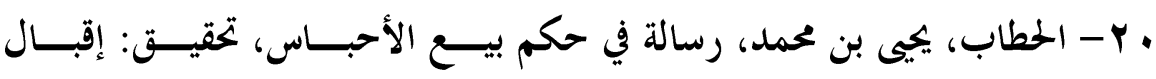

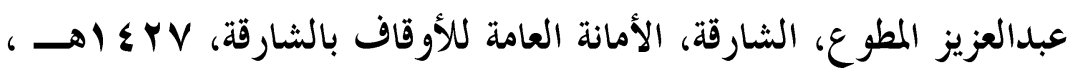
. T

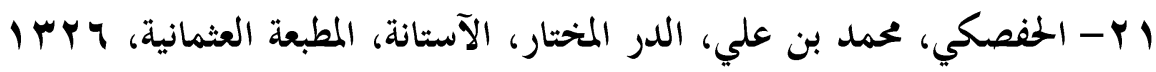


Y r T- الدسوقي، محمد عرفة، حاشية الدسوقي على الشرح الكبير، القاهرة، مطبعة

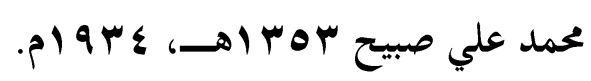

بr - الشيرازي، إبراهيم بن علي، المهذب، مصر، مطبعة عيسى البابي الحلبي.

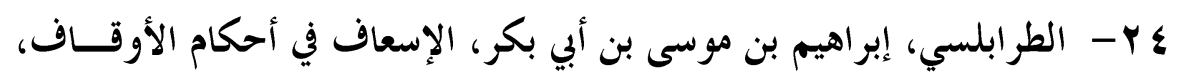

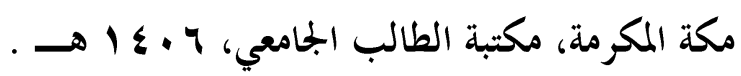

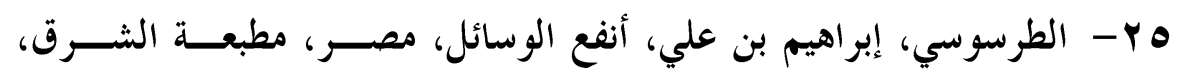
( צr - الكاساين، علاء الدين بن مسعود بن أحمد، بدائع الصنائع في ترتيب الشرائع

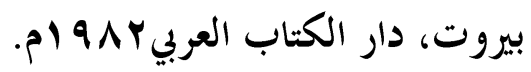

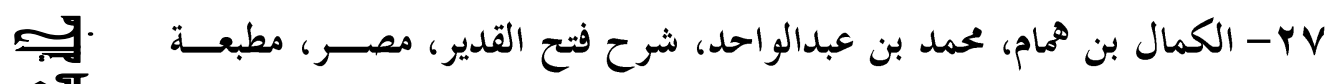
궉.

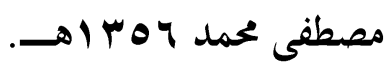

$\frac{\frac{\pi}{3}}{=\frac{4}{3}}$

rrA A - المرادي، علي بن سليمان، الإنصاف في معرفة الر اجح من الحلاف، القاهرة،

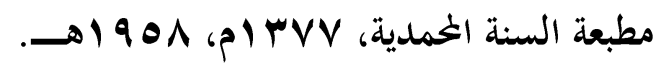

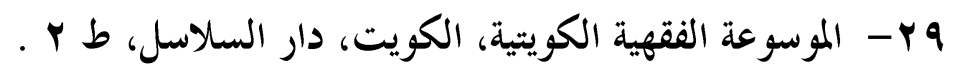

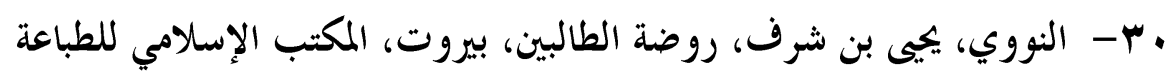

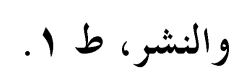
ا أب- أنس الزرقا، الوسائل الحديثة للتمويل والاستثمار ، ضمن ندوة إدارة وتثمير

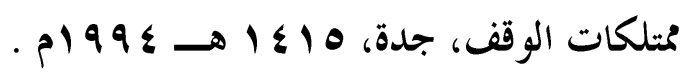

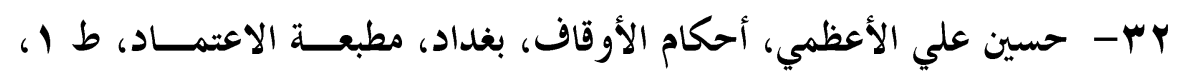
. $19 \leq 9$ ، 19 


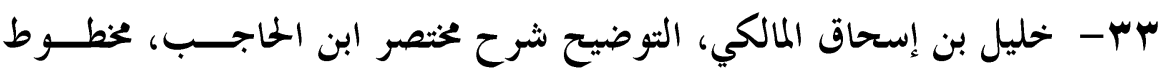

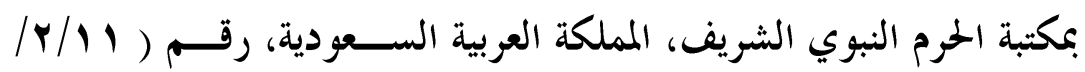

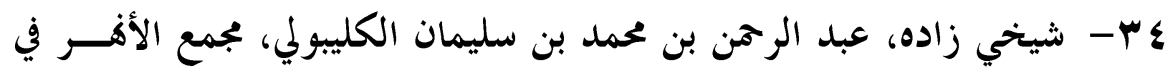

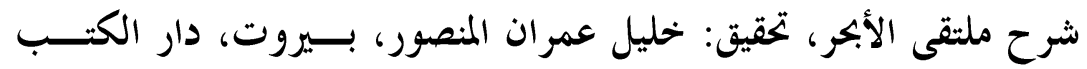

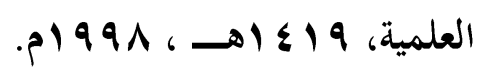

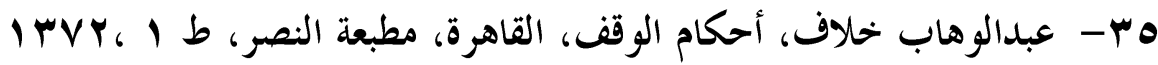

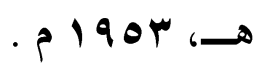

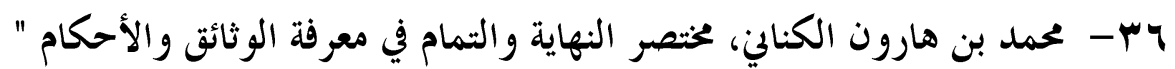

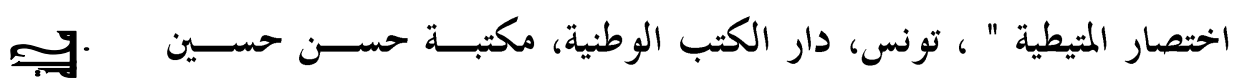

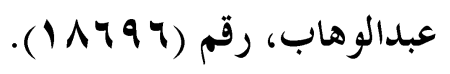

$\frac{\pi}{3}$



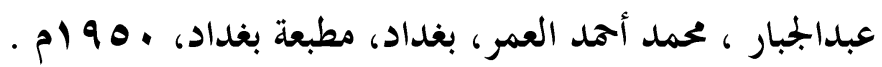

^r- علي محيي الدين القره داغي، استثمار الوقف وطرقه القديـــة والحديثـة،

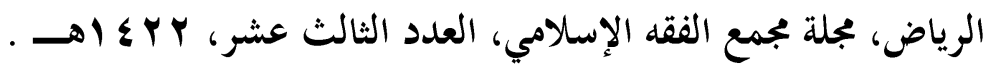

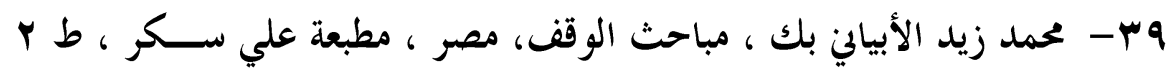
. 1911 ، $\rightarrow$ Irrq، • ـ- محمد شفيق العاني، أحكام الأوقاف، بغداد، الشركة الإسـلامية للطباعـة

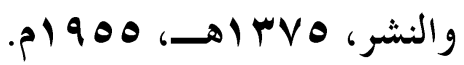
اء- محمد عبيد الكبيسي، أحكام الوقف في الشريعة الإسلامية، بغداد، مطبعسة

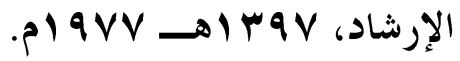


بـ- محمد قدري باشا، قانون العدل والإنصاف، مصر، المطبعة الأميرية الكبرى

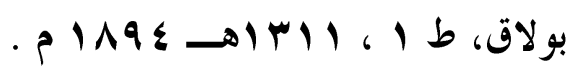

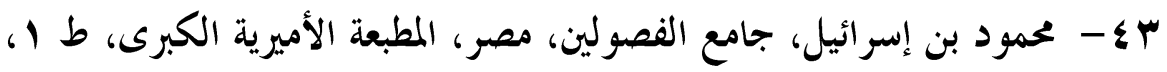

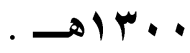

؟ ـ- مصطفى الرحيباني السيوطي، مطالب أولي النهى في شرح غايسـة المنتـهى،

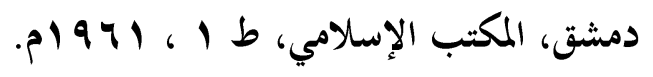

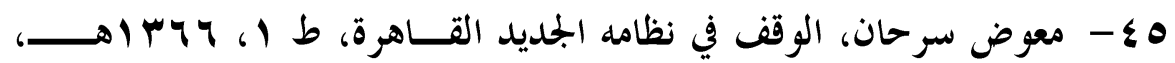

$$
\text { . p) } 9 \leq V
$$

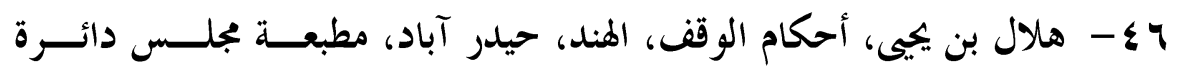

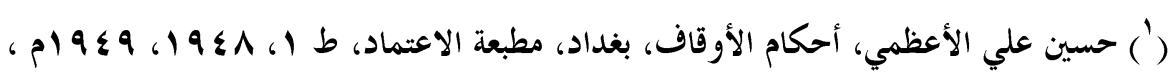

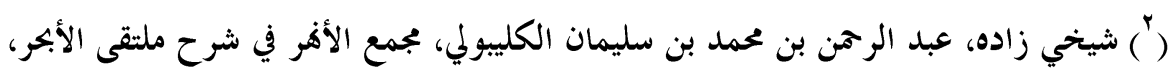

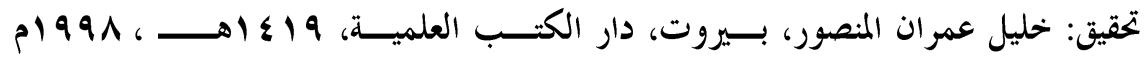
. (0) $1 \leqslant / \Gamma)$

(r) ابن مفلح، إبراهيم بن محمد بن عبد الله، المبدع شرح المقعع، الرياض، دار عسلم الكتــب،

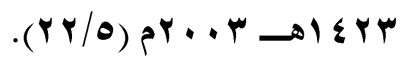

(צ) ابن عابدين، محمد أمين بن عمر، ، رد الختار على الدر المختار، الآستانة، المطبعـة العثمانيسة،

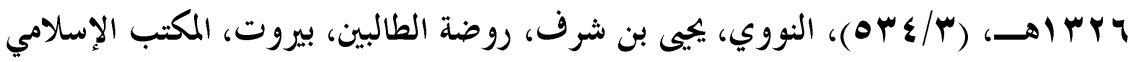

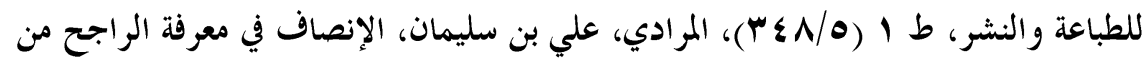

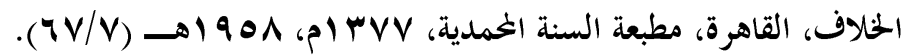

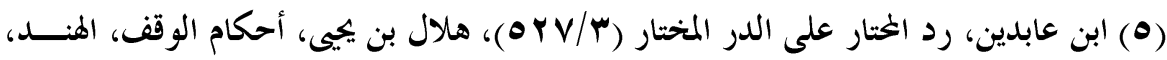

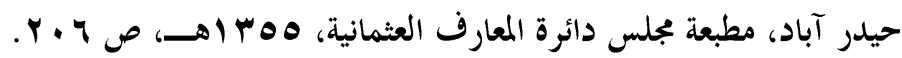

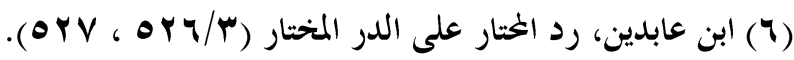


(V) ابن عابدين، رد الختار على الدر المختار (ب/ع ه ه)، الخطيب الشربيني، محمد بــن محمــد،

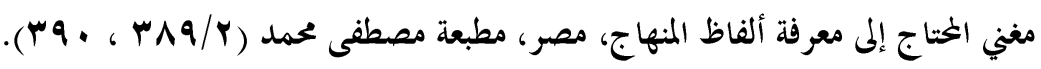

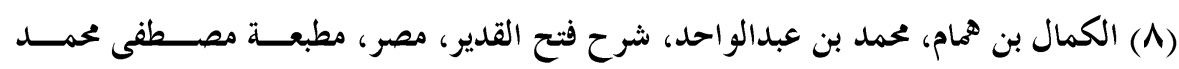

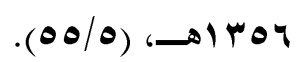

$$
\begin{aligned}
& \text { (9) ابن عابدين، رد الختار على الدر المختار (ب/سهـ). } \\
& \text { (• (1) ابن عابدين، رد الختار على الدر المختار (س/Mهـه). }
\end{aligned}
$$

(1) الحصاف أحد بن عمرو، كتاب أحكام الأوقاف، القاهرة، مكتبة الثقافة الإسـالامية، ص

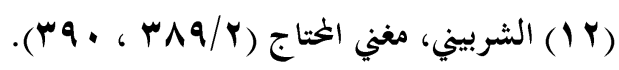

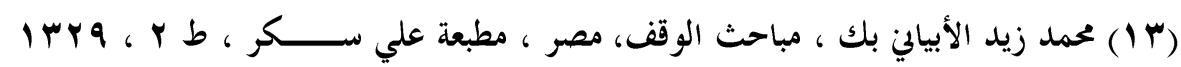
هـ ، 19 (9V AV، محمد عبيد الكبيسي، أحكام الوقف في الشريعة الإسلامية، بغداد،

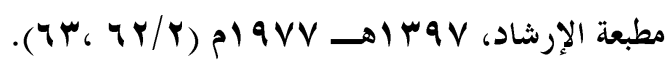

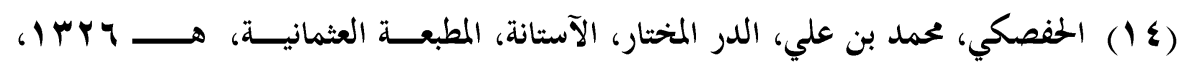

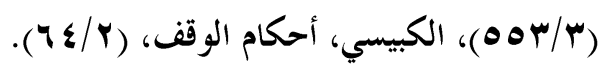

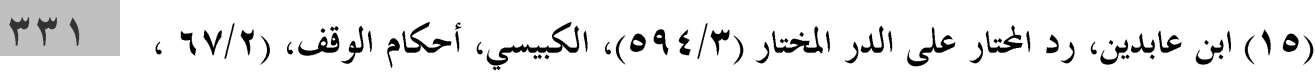

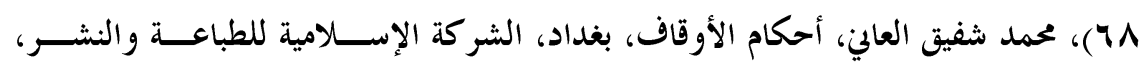

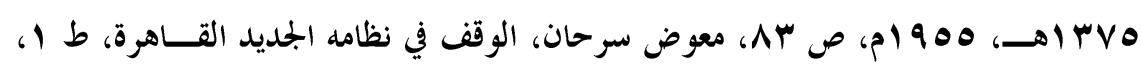

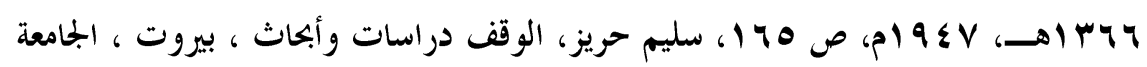

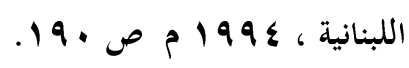

(7 (17) الحصاف، أحكام الأوقاف، ص 77.

(IV) الطر ابلسي، إبراهيم بن موسى بن أبي بكر، الإسعاف في أحكام الأوقاف، مكة المكرمــة،

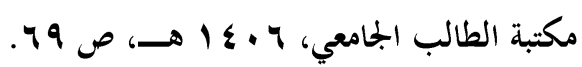

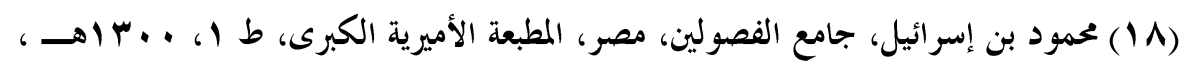
$\cdot(r \cdot / r)$ 
(9 (1) ابن نجيم الحنفي، البحر الرائق شرح كتز الدقائق، مصر، المطبعة العلمية، ط | ، 1 اب اه

$$
\text { . }(r \circ \varepsilon / 0)-6
$$

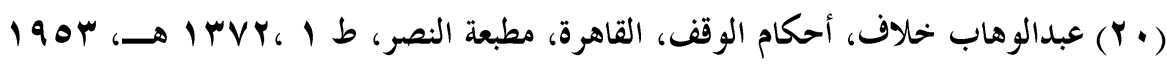

$$
\text { م }
$$

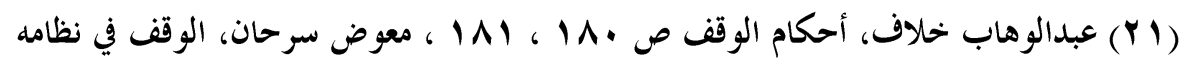

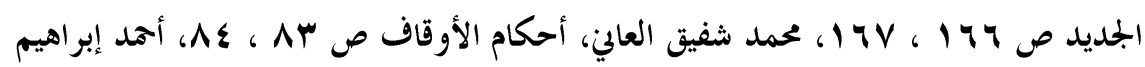

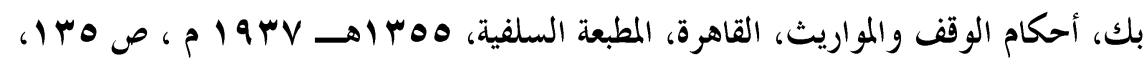

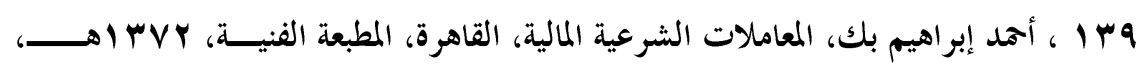

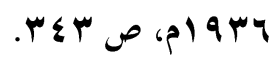

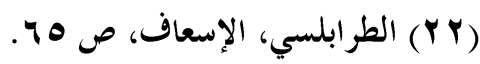

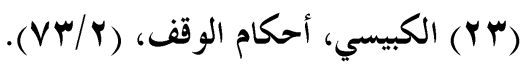

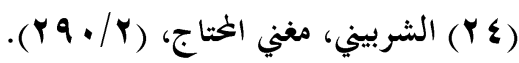

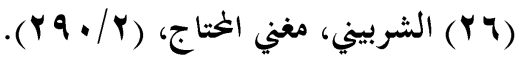

(YV)

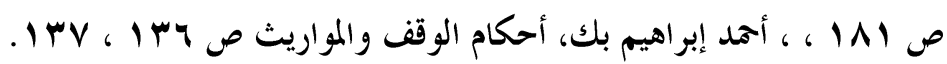

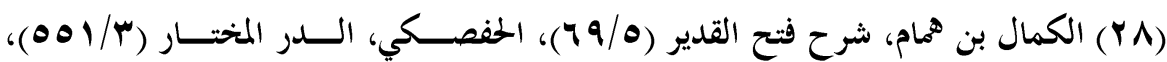

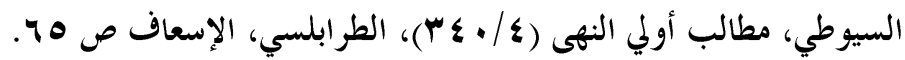

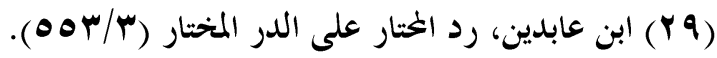

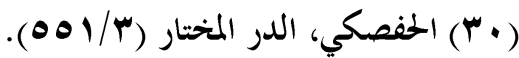
(اب) الحخرشي الحسن بن رحال، شرح الخرشي على مختصر خليل، القاهرة، المطبعة الأميزيسـة،

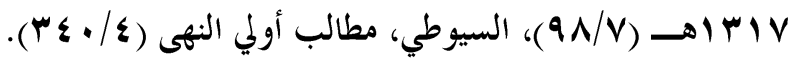

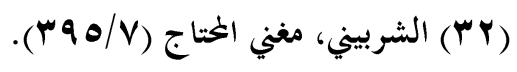


(بT) ابن حجر الهيتمي، أحمد بن محمد بن علي، تحفة الغتاج في شرح المنهاج، دراسة وتحقيـقي:

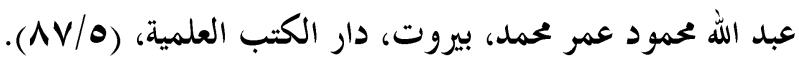

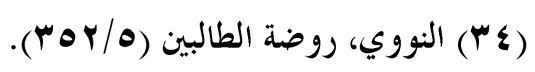

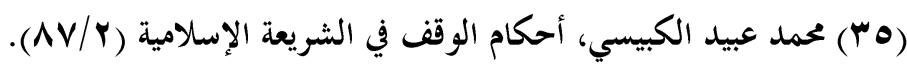

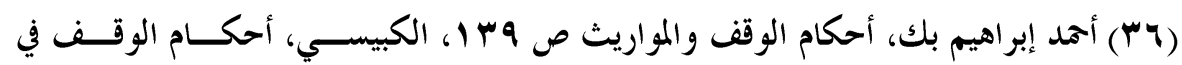

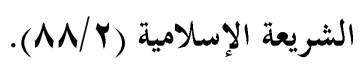

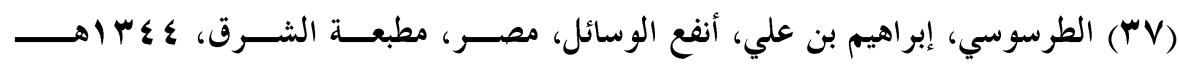

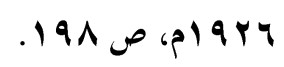

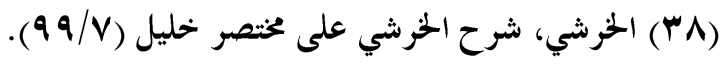

ขี.

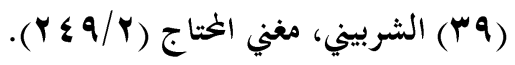

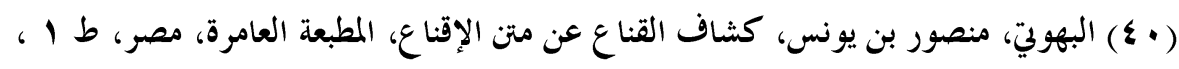

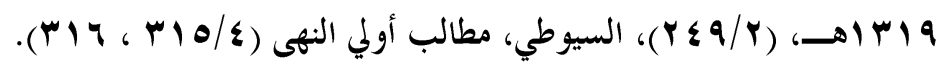

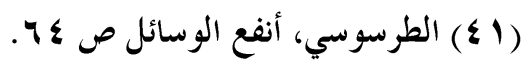

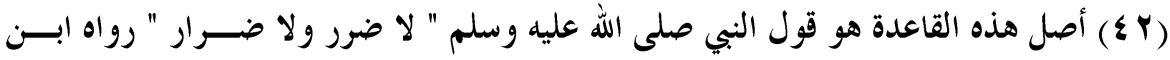

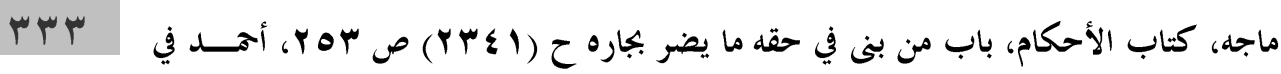

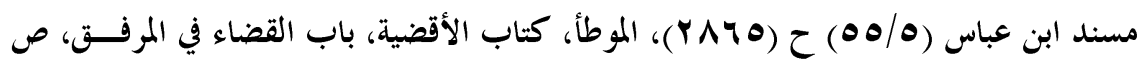

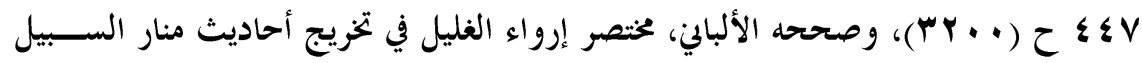

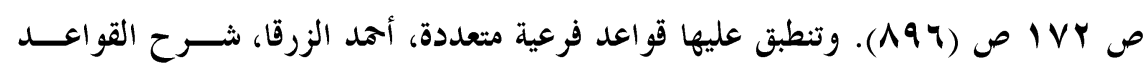

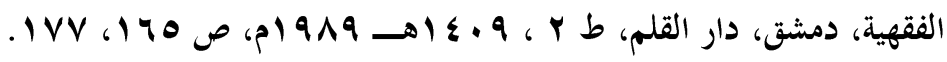

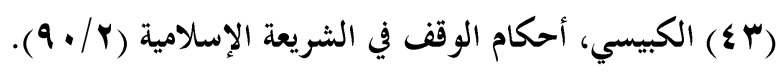

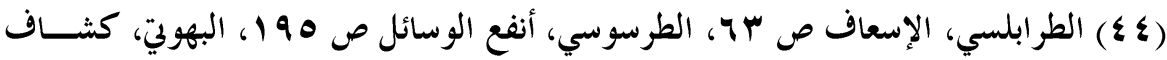

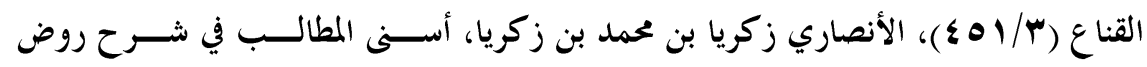

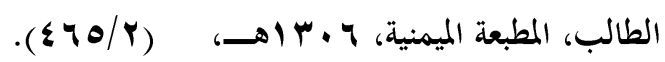

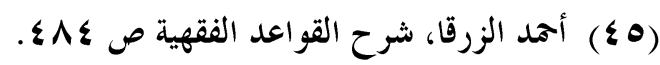




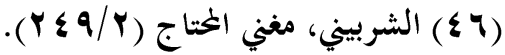

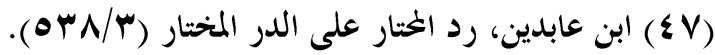

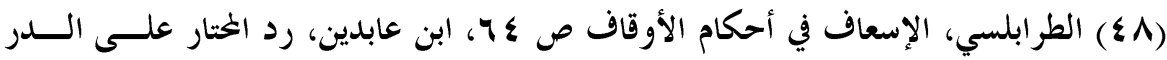

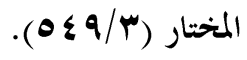

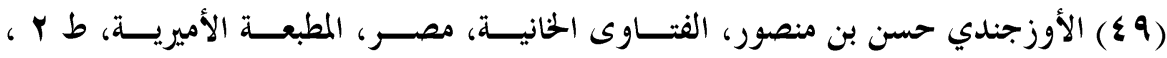

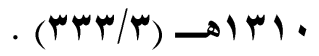

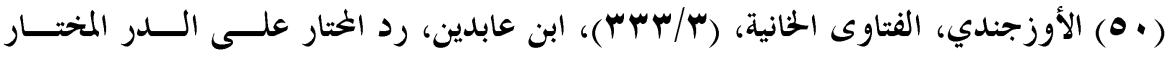

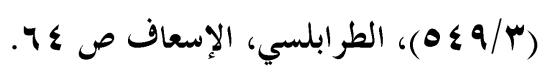

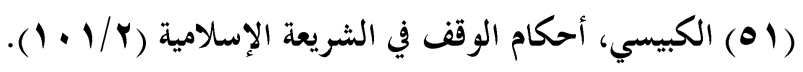

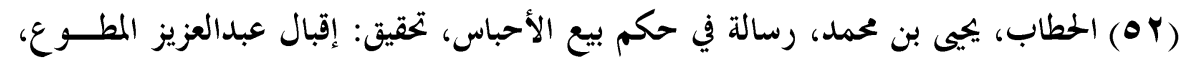

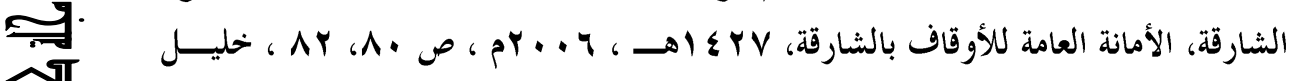

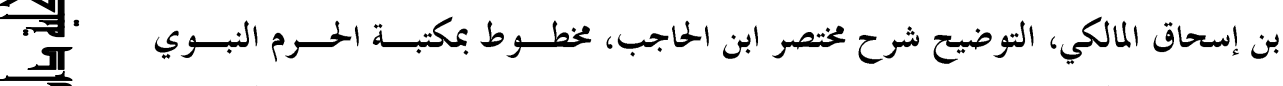

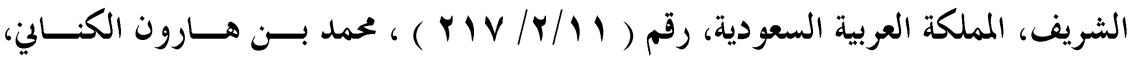

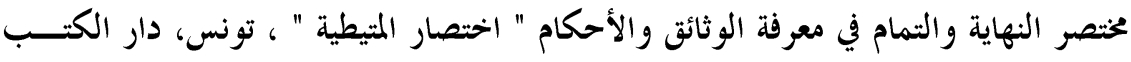

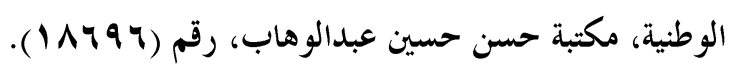

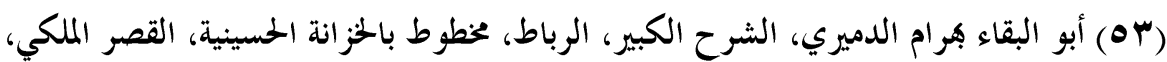

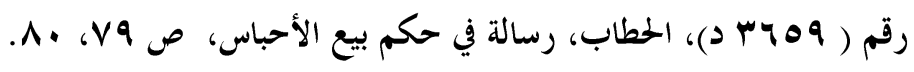

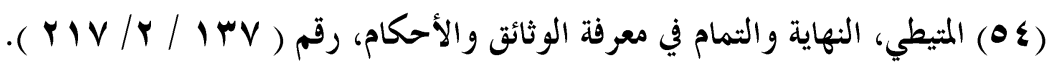

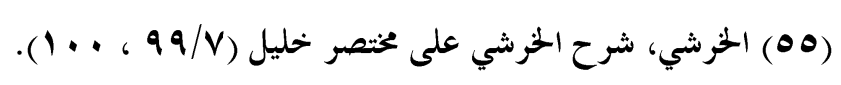

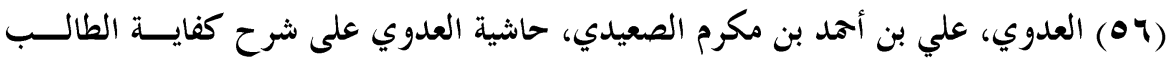

$$
\text { الربالين، (1/ (1) (1). }
$$

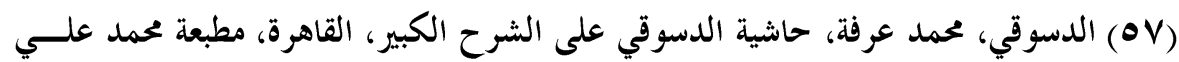

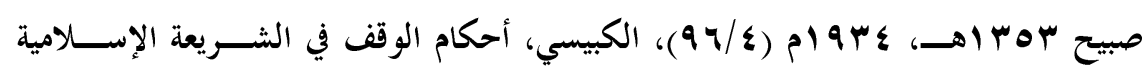

$$
\text { (1. }(1 \cdot r / Y)
$$

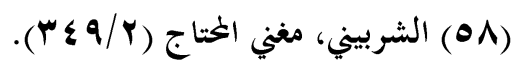




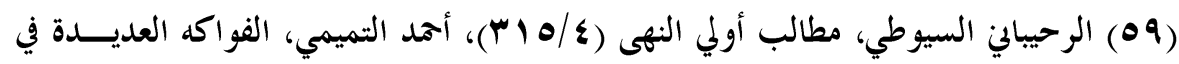

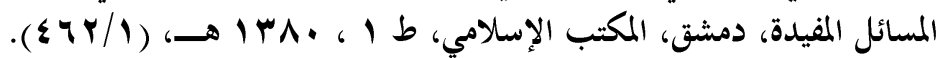

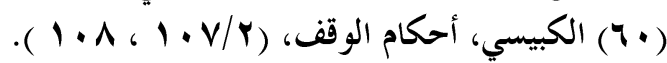

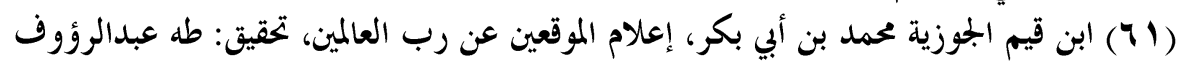

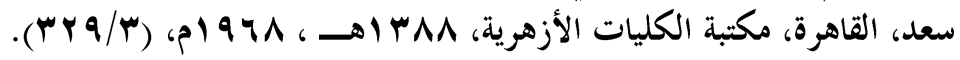

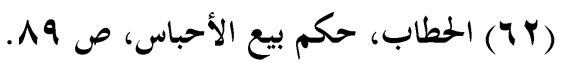

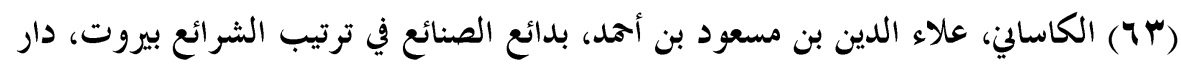

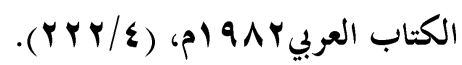

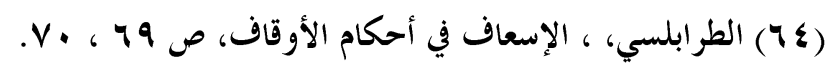

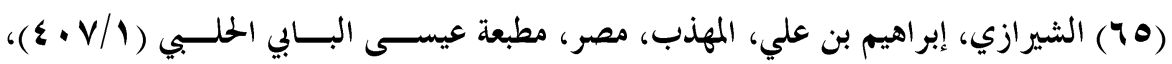

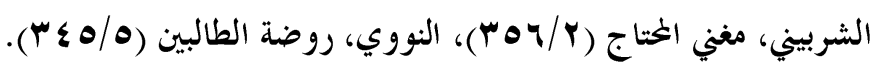

곡.

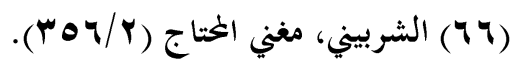

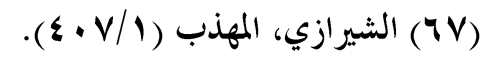

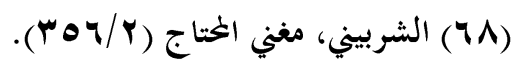

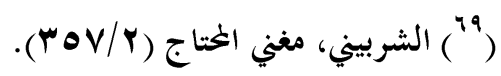

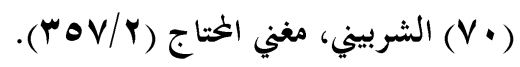

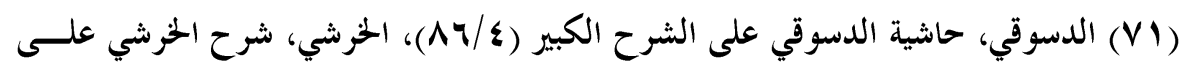

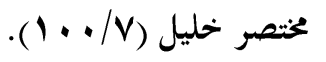

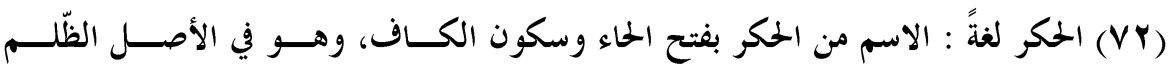

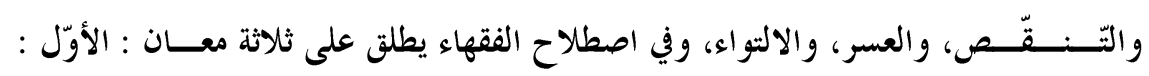

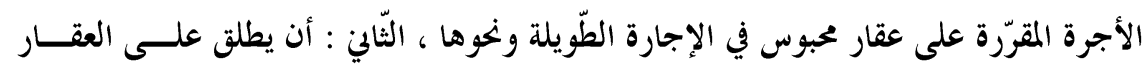

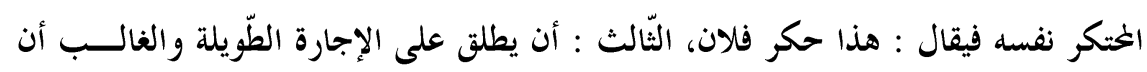

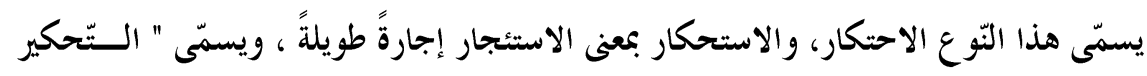

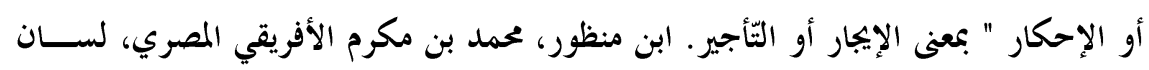

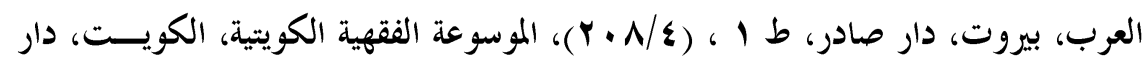

$$
\text { السلاسل، ط ب، (OV/I9). }
$$


(VT)

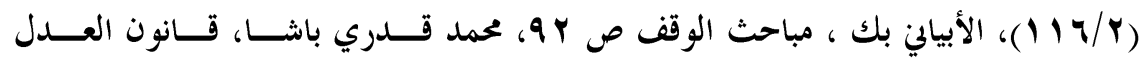

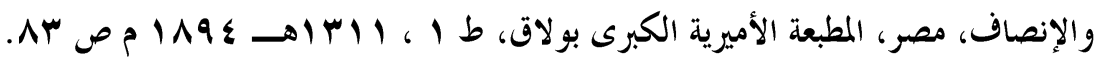

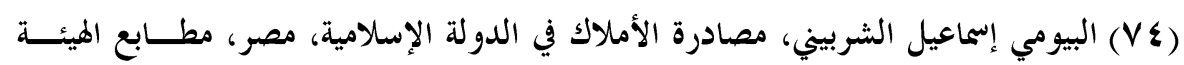

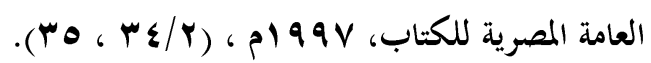

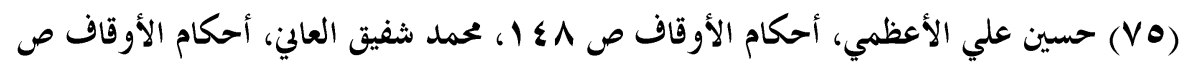
TA1

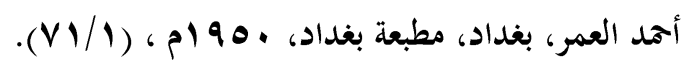

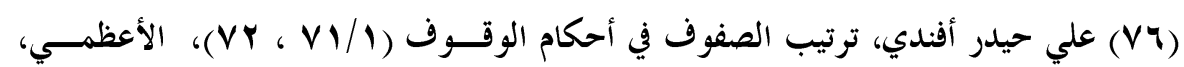

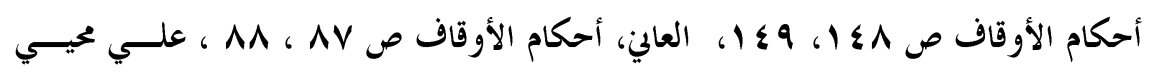

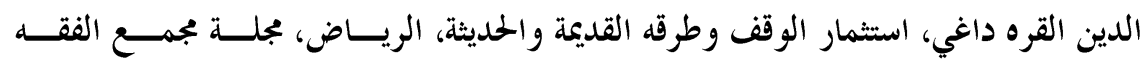

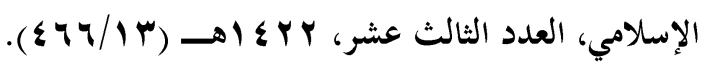

$$
\begin{aligned}
& \text { سليم حريز، الوقف دراسات وأبحاث ص ه ه . (VV) }
\end{aligned}
$$

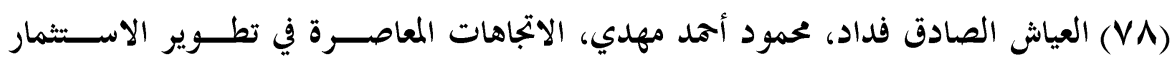

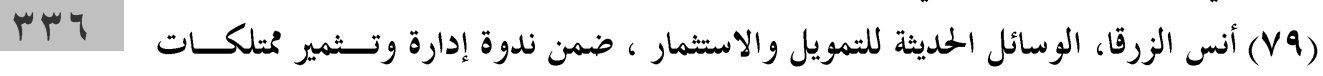

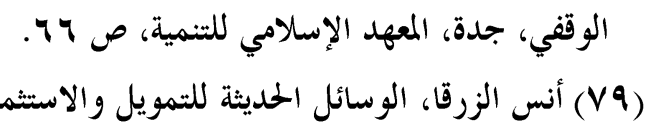

